NBER WORKING PAPER SERIES

\title{
DISCONTINUOUS BEHAVIORAL RESPONSES TO RECYCLING LAWS AND PLASTIC WATER BOTTLE DEPOSITS
}

\author{
W. Kip Viscusi \\ Joel Huber \\ Jason Bell \\ Caroline Cecot \\ Working Paper 15585 \\ http://www.nber.org/papers/w15585
}

\author{
NATIONAL BUREAU OF ECONOMIC RESEARCH \\ 1050 Massachusetts Avenue \\ Cambridge, MA 02138 \\ December 2009
}

This research was supported in part by a grant from EPA to Vanderbilt University. The views expressed herein are those of the author(s) and do not necessarily reflect the views of the National Bureau of Economic Research.

NBER working papers are circulated for discussion and comment purposes. They have not been peerreviewed or been subject to the review by the NBER Board of Directors that accompanies official NBER publications.

(C) 2009 by W. Kip Viscusi, Joel Huber, Jason Bell, and Caroline Cecot. All rights reserved. Short sections of text, not to exceed two paragraphs, may be quoted without explicit permission provided that full credit, including $(\mathcal{O}$ notice, is given to the source. 
Discontinuous Behavioral Responses to Recycling Laws and Plastic Water Bottle Deposits

W. Kip Viscusi, Joel Huber, Jason Bell, and Caroline Cecot

NBER Working Paper No. 15585

December 2009, Revised December 2010

JEL No. K23,K32,Q50,Q58

\begin{abstract}
Economic theory predicts that individual recycling behavior gravitates toward extremes - either diligent recycling or no recycling at all. Using a nationally representative sample of 3,158 bottled water users, this article finds that this prediction is borne out for consumer recycling of plastic water bottles. Both water bottle deposits and recycling laws foster recycling through a discontinuous effect that converts reluctant recyclers into diligent recyclers. Within this context, a number of factors influencing recycling emerge. The warm glow from being both an environmentalist and an environmental group member is about equal to the monetary value of 5 cent bottle deposits. Respondents from states with stringent recycling laws and bottle deposits have greater recycling rates. Consistent with recycling being a threshold response, the efficacy of these policy interventions is greater for those who do not already recycle, have lower income, and do not consider themselves to be environmentalists.
\end{abstract}

W. Kip Viscusi

Vanderbilt Law School

13121 st Avenue South

Nashville, TN 37203-1181

and NBER

kip.viscusi@vanderbilt.edu

Joel Huber

Fuqua School of Business

Duke University

Durham, NC 27706

Joel.Huber@Duke.edu
Jason Bell

Fuqua School of Business

Duke University

Durham, NC 27706

jason.bell@duke.edu

Caroline Cecot

Vanderbilt Law School

131 21st Avenue South

Nashville, TN 37203

cecot@fas.harvard.edu 


\section{Introduction}

Waste associated with plastic water bottles has become an issue of substantial national prominence. In six years, U.S. sales of bottled water for individual consumption tripled from about 12 billion water bottles in 2000 to 36 billion in 2006. ${ }^{1}$ In 2008 alone, U.S. consumption of bottled water was more than 28 gallons per capita, with industry wholesale dollar sales exceeding \$11 billion. ${ }^{2}$ Bottled water typically comes in polyethylene terephthalate (PET) bottles. More than 2 million tons of PET bottles, including those for beverages other than water, were incinerated or left in landfills in 2006. The Container Recycling Institute estimates that increasing PET recycling rates to about 85\% would save more than 60 trillion BTUs and avoid about a million metric tons of carbon equivalent greenhouse gas emissions. Plastic water bottles comprise almost half of the total PET bottle sales and represent a growing share of sales. However, bottle deposit laws in most states do not include these water bottles. This paper examines the efficacy of the economic incentives generated by policies that encourage the recycling of these plastic water bottles. ${ }^{3}$

There are two principal policy instruments that promote water bottle recycling — bottle deposits and recycling laws. Bottle deposits for plastic water bottles establish a financial incentive to foster recycling while recycling laws generally encourage that behavior by reducing the time cost and increasing the convenience cost of recycling. ${ }^{4}$ In some instances recycling

\footnotetext{
${ }^{1}$ See the Container Recycling Institute (2008) for detailed statistics through 2006.

${ }^{2}$ See Rodwan (2009).

${ }^{3}$ We do not analyze whether increased recycling of water bottles would pass a cost-benefit test. Such an analysis would need to consider the implementation and operating costs of the various policies against the benefits of reducing greenhouse gas emissions, increasing landfill space, saving natural resources through the possibility of reuse, and experiencing the warm glow benefits of recycling. See, e.g., Kinnaman (2006) and Morris, Smith, and Hlavka (2005). To the extent that a state or a municipality would like to increase its water bottle recycling through a bottle deposit bill or other recycling law, however, our analysis identifies the impact that each policy is likely to have on individual recycling behavior.

${ }^{4}$ There also may be financial incentives through penalties imposed for noncompliance if recycling is mandatory.
} 
laws may impose monetary penalties on failure to recycle properly. Recycling laws exhibit a range of policy stringency, from requiring local recycling to merely defining it as a goal.

While the economics literature on recycling behavior has been growing, this study is novel in its focus on individual recycling behavior for a nationally representative sample that can be linked to different recycling law regimes in the fifty U.S. states. ${ }^{5}$ To date, there have been no comprehensive studies of plastic water bottle recycling or national studies of individual recycling behavior. Most studies have focused on states or narrowly defined regions. ${ }^{6}$ Some studies of material-specific recycling have used individual data, but have not analyzed the different state law regimes, have not used nationally representative samples, and have not focused on plastic water bottles specifically. ${ }^{7}$

Our study uses an original national data set of 3,158 households. Data at the individual level make it possible to examine the determinants of recycling decisions controlling for household characteristics and to examine the different levels of individual recycling rates. Many of the variables included in our analysis, such as whether the respondent is a member of an environmental organization, are unique to our recycling study. On a theoretical basis, we predict

\footnotetext{
${ }^{5}$ Jenkins et al. (2003) and Yang and Innes (2007) review previous empirical recycling studies. Most, but not all studies in the literature have analyzed recycling behavior on a regional basis. These studies include Fullerton and Kinnaman (1996), Callan and Thomas (1997), Nester and Podolsky (1998), Hong and Adams (1999), Van Houtven and Morris (1999), and Suwa and Usui (2007). Kinnaman and Fullerton (2000) examine community-level recycling behavior using a national dataset, and Jenkins et al. (2003) analyze material specific recycling for a sample in 20 metropolitan statistical areas (MSAs) of middle and upper-middle income households who had curbside collection available. Ashenmiller (2009) used individual survey data from CA to examine the effect of bottle bills and concluded that they increase recycling.

${ }^{6}$ Three such regional studies are Saltzman et al.’s (1993) analysis of glass and newspaper recycling (by quantity) in 53 communities in PA and NJ, Beatty et al.'s (2007) analysis of aluminum, glass, and plastic recycling (by quantity) in regional CA communities, and Yang and Innes's (2007) regional Taiwan analysis of paper, metal, plastic, and glass recycling (by weight).

${ }^{7}$ Three studies using household-level data are Reschovsky and Stone's (1994) analysis of the proportion of many different materials recycled in an upstate NY county, Sterner and Bartelings' (1999) analysis of recycling (by weight) of materials other than plastic using regional data in Sweden, and Jenkins et al.'s (2003) analysis of the recycling (by proportion recycled) of newspaper, glass bottles, aluminum, plastic bottles, and yard waste by middle and upper income households in 20 major MSAs. Kinnaman (2005) examines the effect on curbside recycling of legal contexts categorized by a survey of state officials reported in Biocycle magazine by Kaufman et al. (2004).
} 
that people gravitate toward an extreme of either being a non-recycler or a diligent recycler, a mechanism which can only be revealed using individual data rather than aggregative data.

The use of individual data also makes it possible to examine the individual heterogeneity of the recycling responses to the incentives created by the recycling laws and bottle deposit laws of different states. To capture the incentive effects of these laws, our study uses our own detailed categorization of state recycling statutes and bottle bills presented in Appendix B. The data set enables us to answer several kinds of questions. Are some segments of the population less motivated by recycling policies, and does their responsiveness hinge on the particular form of intervention? Will those in upper income groups respond to the financial incentives of bottle deposits or be deterred by the time costs associated with recycling? Differences in individuals’ valuation of the environment also may be consequential if environmentalists already recycle without additional financial incentives. Our results demonstrate a substantial muting of the financial incentives for recycling for those with higher income levels and strong environmental preferences.

The next section of this paper presents a conceptual model of recycling behavior, which predicts that once people begin to recycle they tend to become diligent recyclers so that successful policy interventions have a discontinuous effect on individual behavior. After describing the sample and the recycling policy regimes, Section 3 presents overview statistics indicating a strong bimodal aspect to recycling behavior. The regression analyses of the determinants of the fraction of bottles recycled in Section 4 and the use of curbside recycling and bottle returns in Section 5 provide estimates of the efficacy of the different recycling interventions. Section 6 presents corroborative results on the effect of bottle deposits based on the natural experiments in Oregon and Connecticut during the course of survey administration. 
Section 7 concludes. Incentives matter, consistent with both economic theory and the hypothesized discontinuous recycling decision.

\section{The Consumer's Recycling Decision}

Recycling decisions depend on what items the consumer has purchased. Following the standard dynamic programming approach, we assume that in the first stage the consumer chooses the consumption mix conditional on the optimal disposal and recycling decisions in the second stage. The consumer makes the purchase decisions in the initial period anticipating optimal disposal thereafter so that it is appropriate to analyze the second stage disposal and recycling decision, taking as given the prior purchase decisions. ${ }^{8}$

\section{$\underline{\text { Recycling Decision Notation and Framework }}$}

Although not all disposal options are available in every locale, if we abstract from littering, there are three possible ways to dispose of plastic bottles: curb recycling, denoted by c, returning the bottle for deposits, $d$, and putting the bottles in the garbage, g. If we denote the total number of bottles as $\mathrm{x}$, then $\mathrm{x}=\mathrm{c}+\mathrm{d}+\mathrm{g}$. For each bottle returned for deposit, the consumer receives a unit price.$^{9}$

Let the utility for each disposal mode be represented by an additively separable function of the environmental benefit minus the net cost of disposal. The person's wage rate, w, reflects opportunity cost of time. ${ }^{10}$ We also assume there is no warm glow benefit from bottles that are

\footnotetext{
${ }^{8}$ Similar formats that focus on the recycling stage decision are used by Kinnaman and Fullerton (2000), Jenkins et al. (2003), and Beatty et al. (2007). Bohm (1981) considers a different model of the refund-disposal decision that involves the time decision of when to stop using the product and dispose of it. Our analysis assumes that individuals must choose a way to dispose of their water bottles once they are empty.

${ }^{9}$ If the bottles are returned to a recycling center in a no deposit state, the price is zero.

${ }^{10}$ For simplicity, we abstract from the exogenous labor supply decision and focus on the wage rate w. Assuming a fixed predetermined number of hours worked, the wage rate also serves as a measure of the level of income.
} 
not recycled but that environmental benefit that the consumer derives for each bottle recycled is the same whether the bottle is recycled at the curb or returned for deposit. ${ }^{11}$

For each recycling mode, there is a fixed cost time component as well as a time cost component that increases linearly with the number of bottles recycled. Thus, the time commitment $\mathrm{t}_{\mathrm{c}}$ for recycling $\mathrm{c}$ bottles with curbside recycling is

$$
\mathrm{t}_{\mathrm{c}}=\mathrm{t}_{\mathrm{c} 0}+\mathrm{t}_{\mathrm{c} 1 \mathrm{C}}
$$

and for d bottles returned for deposit it is

$$
t_{d}=t_{d 0}+t_{d 1} d
$$

and for $\mathrm{g}$ bottles put in the garbage it is

$$
\mathrm{t}_{\mathrm{g}}=\mathrm{t}_{\mathrm{g} 0}+\mathrm{t}_{\mathrm{g} 1 \mathrm{~g} \cdot 12}
$$

The personal cost of this time commitment is $t_{c} w, t_{d} w$, and $t_{g} w$ for the three different types of bottle disposal. States that have effective recycling programs, such as those with convenient curbside recycling and accessible recycling centers, promote recycling by decreasing the recycling cost components. In some instances the cost structure may be different, as when drinking bottled water at a sporting event or while traveling, in which case even diligent recyclers may not find it desirable to recycle their bottles.

The attractiveness of any recycling option will depend on the other choices available and whether the particular recycling mode is already being used, in which case the fixed cost component of the time cost drops out. There are many commonalities across the different recycling options, and these general economic aspects of the decision will be our focus here rather than attempting to inventory results for every disposal combination.

\footnotetext{
${ }^{11}$ This benefit term may, of course, vary with demographic characteristics such as whether the person is a member of an environmental group. Kinnaman (2006) provides an overview of the literature on the utility benefit of recycling. 12 The linearity assumption in this model is the key assumption leading to the corner solution outcome.
} 


\section{Curbside Recycling Versus Garbage}

The recycling decisions in different contexts involve similar economic issues that can be illustrated by considering the binary decision of whether to recycle n bottles curbside or to put the bottles in the garbage, where we assume that this is the initial disposal for each mode. ${ }^{13}$ Curbside recycling will be more attractive if

$$
\text { en }-\left(t_{c 0}+t_{c 1} n\right) w>-\left(t_{g}+t_{g} n\right) w \text {. }
$$

Recycling at the curbside is preferable if the environmental benefit exceeds any net cost in disposal time, or

$$
\text { en }>\left[\left(t_{c 0}-t_{g 0}\right)+\left(t_{c 1}-t_{g 1}\right) n\right] w \text {. }
$$

How much people will choose to recycle will depend on a succession of marginal choices, but it may be preferable to adopt a common recycling strategy for all bottles. Suppose that it is desirable for a consumer to recycle $\mathrm{n}$ bottles at the curb, and that the consumer already uses garbage disposal for other items so that $\mathrm{t}_{\mathrm{g} 0}=0 .{ }^{14}$ Then the overall comparison of the benefits of recycling these $n$ bottles rather than putting them in the garbage is

$$
\text { en }-\left(t_{c 0}+t_{c 1} n\right) w>-t_{g 1} n w \text {, }
$$

or

$$
\mathrm{e}>\frac{\mathrm{t}_{\mathrm{c} 0}}{\mathrm{n}}+\left(\mathrm{t}_{\mathrm{c} 1}-\mathrm{t}_{\mathrm{g} 1}\right) \mathrm{w} \text {. }
$$

For the $n+1$ 'st bottle, the use of curbside recycling will be preferred if

$$
\mathrm{e}-\mathrm{t}_{\mathrm{c} 1} \mathrm{w}>-\mathrm{t}_{\mathrm{g} 1 \mathrm{~W}}
$$

which can be written as

$$
\mathrm{e}>\left(\mathrm{t}_{\mathrm{c} 1}-\mathrm{t}_{\mathrm{g} 1}\right) \mathrm{w}
$$

\section{But since}

\footnotetext{
${ }^{13}$ If the consumer already uses the garbage disposal mode for other items, $t_{\mathrm{g} 0}=0$.

14 The analysis if no garbage disposal is already being used is generally less realistic.
} 


$$
\frac{\mathrm{t}_{\mathrm{c} 0}}{\mathrm{n}}+\left(\mathrm{t}_{\mathrm{c} 1}-\mathrm{t}_{\mathrm{g} 1}\right) \mathrm{w}>\left(\mathrm{t}_{\mathrm{c} 1}-\mathrm{t}_{\mathrm{g} 1}\right) \mathrm{w}
$$

if inequality 7 is satisfied so that it is desirable to recycle $n$ bottles, then it will also be desirable to recycle $n+1$ bottles. Because of the small incremental cost of recycling an additional bottle, consumers will tend to gravitate to corner solutions of no recycling or complete recycling. Returning bottles for deposit as opposed to disposing of the bottles in the garbage also leads to a similar corner solution, as does the decision to use curbside recycling or to return the bottles for deposit.

\section{Empirical Predictions}

This exploration of recycling decisions has led to several empirical predictions. First, people will exhibit discrete modal choices in their recycling behavior. Thus, to the extent that policies such as curbside recycling laws or bottle deposit laws are influential, people will switch from doing little or no recycling of that type to using that mode almost exclusively. Because of this discontinuous response, there should be few individuals with intermediate levels of recycling for any particular recycling mode. Second, placing a high value on the warm glow effect increases the attractiveness of recycling by curbside or through bottle returns as compared to putting the bottles in the garbage. If the environmental utility value is identical for both recycling and returns, this environmental benefit component will not have a differential effect across those domains. Third, bottle deposits increase the likelihood of recycling bottles. 3. Sample Characteristics and Recycling Laws

The data set used in the empirical analysis is from a national survey of households undertaken for this study by Knowledge Networks (KN) in 2008 and 2009. The KN panel is based on probability sampling of both online and offline populations. If a person does not have internet access or a computer, KN provides the necessary hardware and internet access. Our 
survey is Web-based and was administered to a nationally representative sample, with a $71 \%$ response rate. ${ }^{15}$ The characteristics of the full sample, as reported in Appendix Table A1, closely parallel the characteristics of the adult U.S. population. Of the 5,213 survey participants, 3,158 are bottled water users. ${ }^{16}$ Based on the summary of the sample characteristics in Table A1, bottled water consumption is quite widespread across the population. Compared to those who do not drink bottled water, bottled water drinkers are more likely to be female, younger, nonwhite, and have high income. Our empirical analysis focuses on the bottled water subsample, because this is the population for which the recycling decision is pertinent. While the entire survey took around 25 minutes, the sections on individual attitudes and practices related to bottled water and recycling took less than 10 minutes. Appendix Table A2 summarizes the pertinent survey questions.

While the data only pertain to the amounts of plastic water bottles recycled, the survey did include a recycling question that asked respondents to compare their recycling of all recyclable materials relative to their neighbors. As indicated by the data in Appendix Table C1, the self-assessed relative degree of recycling is similar for bottled water users and those who do not drink bottled water. The main result of interest is that the distribution across response categories is remarkably similar for those in the plastic water bottle sample and for those not in this group suggesting that an analysis of recycling aluminum cans or newspapers would produce similar results.

\footnotetext{
${ }^{15}$ Our use of KN for our EPA-funded water surveys has been specifically reviewed and approved by the Office of Information and Regulatory Affairs, U.S. Office of Management and Budget (OMB). The KN panel also meets the U.S. government's quality standards for RDD surveys. For additional information on the characteristics of the KN panel, see http://www.knowledgenetworks.com/knpanel/KNPanel-Design-Summary.pdf.

${ }^{16}$ To be classified as a bottled water user the person must meet two tests. First, the person must "use bottled water at home, work, exercise, car, or other." Second, the person must have "bought water in plastic bottles in the past month.”
} 
The focus of our analysis is on the recycling of plastic bottles for bottled water. As a result, we restrict the sample to the 3,158 people who indicated that they use bottled water. ${ }^{17}$ The focal recycling question for the plastic bottles was the following: "Out of every 10 plastic bottles, how many would you say that you recycled or returned for reuse?” On average, the sample members indicated they recycled or returned a mean of 6.0 out of 10 plastic water bottles. This amount is greater than the U.S. Government Accountability Office's (GAO) report of an estimate of total plastic bottle recycling rate of $24 \%$ in 2006 based on data from the National Association of PET Container Resources, which reports a $27 \%$ estimate for $2008 .^{18}$ However, those statistics do not pertain to the household recycling rate of plastic water bottles, which is the focus of our study. The relatively low national recycling rate figures also include the $69.1 \%$ of all bottled water that is consumed away from home at restaurants, workplaces, hotels, sporting events, conventions, and other locales. ${ }^{19}$ As indicated below, our household recycling patterns are comparable to those found by Jenkins et al. (2003) for areas with curbside recycling for some materials. ${ }^{20}$ If, however, all sample respondents overstated their recycling rate relative to the GAO figure by a common factor, one would multiply all recycling rates by 0.45 .

The matter of interest is less on the average recycling rates than on how reported bottle return rate varies with the different recycling and deposit regimes and, in particular, whether the economic incentives created by these regimes influence recycling behavior. Consideration of

\footnotetext{
${ }^{17}$ The sample is restricted to the 3,158 respondents who indicated how often they recycle their bottles. Many of the excluded respondents used water cooler containers that were collected on a regular basis by the supplier and consequently did not involve the same kind of recycling decisions being analyzed here.

${ }^{18}$ The U.S. Government Accountability Office (2009) indicated that it "did not independently verify the accuracy and completeness of the data provided by [the environmental nonprofit] organizations." The National Association of PET Container Resources report, which provides the details for the estimate, is available at http://www.napcor.com/pdf/RRate2008.pdf.

${ }^{19}$ See http://www.ers.usda.gov/publications/err1/err1a.pdf.

${ }^{20}$ Jenkins et al. (2003) found that the majority of respondents recycled over $95 \%$ of plastic bottles. Our results similarly show that a majority of respondents recycle 9 or 10 out of 10 plastic bottles. Additionally, the findings of Jenkins et al. suggest a plastic bottle recycling rate of around $69 \%$ using the midpoints of their reported ranges, a number similar to our $60 \%$ result.
} 
relative gradations of recycling behavior in our empirical analysis should be less susceptible to reporting bias than statements of the absolute number of bottles recycled.

Table 1 summarizes the sample characteristics of the variables used in the analysis. In addition to data on recycling practices and state laws, the data include detailed personal characteristic information. Over two-fifths of the sample consider themselves to be environmentalists and $8 \%$ are members of national environmental groups. ${ }^{21}$ This proportion is similar for both bottled water users and non-bottle water users. Bottled water users spend about \$11 per month on bottled water, while non-bottled water users spend no money at all, leading to a sample spending average of just under $\$ 8$ per month on bottled water.

States differ by the extent to which they encourage recycling either through bottle deposit laws and their specific recycling policies. Bottle deposits create a direct financial incentive for recycling bottles for which deposits are required, which in most states do not include plastic water bottles. ${ }^{22}$ The deposit rate is 5 cents per bottle, except in Michigan where the rate is 10 cents. ${ }^{23}$ The unit price deposit raises the price paid at the time of purchase, but for every bottle returned to a recycling location or to stores that accept recycled bottles, the recycler is paid the deposit amount. The bottle can be recycled by anyone and need not be recycled by the original purchaser. ${ }^{24}$ About $16 \%$ of the sample members reside in the states with non-water bottle deposit laws, and only $12 \%$ of the sample resides in the five states (California, Connecticut, Hawaii, Maine, and Oregon) that had bottle deposit laws in 2009 that included plastic water bottles.

\footnotetext{
${ }^{21}$ These groups included Environmental Defense Fund, Greenpeace, National Audubon Society, National Wildlife Federation, Nature Conservancy, Natural Resources Defense Council, and Sierra Club.

${ }^{22}$ See Bohm (1981) for an early detailed analysis of deposit-refund systems.

${ }^{23}$ Separate analyses failed to demonstrate any differential effect of the higher bottle deposits in Michigan.

${ }^{24}$ For example, homeless people and scavengers often collect bottles from litter, garbage, and curbside recycling bins and return the bottles for cash. This leeway no doubt contributes to the role of bottle deposits as an income supplement for the poor, which in turn decreases crime rates. See Ashenmiller (2006, 2009, 2010).
} 
The survey inquired whether the respondent received payment for plastic bottle recycling. The survey responses follow the expected pattern given the bottle deposit regime in the respondent's state of residence. The theory developed earlier suggests that bottle deposit requirements for other types of bottles will increase the recycling of water bottles. We will test whether bottle deposits lead consumers to sort their garbage and bring the bottles for which there are deposits to a recycling center. To the extent that there are fixed costs associated with returning bottles to a recycling center, the additional costs of also bringing the plastic water bottles may be less than if there were no bottle deposit policies. Recycling centers in states with bottle deposit requirements may also include opportunities to recycle plastic water bottles even though there is no payment for such recycling.

There is substantial diversity in the structure of recycling laws across states. State laws often include one or more regulatory components, summarized in Appendix B. For example, a state with mandatory recycling may also include recycling goals. For purposes of categorization, we treat states hierarchically in terms of the most stringent component in the state's recycling law. States are grouped into those that have mandatory recycling or that require an opportunity for recycling for all citizens, those that require local communities to have a recycling plan, those that have recycling goals but lack a specific plan, and, finally, those that have no recycling law.

Our empirical analysis indicates that recycling goals alone do not have a statistically significant positive effect on recycling whereas the other three recycling laws do. Thus, for purposes of our first two overview tables we will denote "effective recycling laws" as those states with mandatory recycling, opportunities for recycling, or regional waste management plans with recycling considerations. 
Table 2 summarizes the recycling practices for water bottle users under different recycling regimes. The average number of bottles out of 10 that are recycled rises from 4.30 for states with no effective recycling law and no water bottle deposit law to 5.86 if the state also has an effective recycling law and to 8.59 if the state also has a water bottle deposit law. All states with a water bottle deposit law also have an effective recycling law.

The most prevalent form of recycling is at curbside. Almost half of all water bottle users use curbside recycling for some of their bottles, while only one-fifth of the sample returns bottles for deposit or takes them to a recycling center. In states with water bottle deposit laws, about half return the bottles for deposit, and the percentage using curbside recycling is not substantially lower than in states without such bottle deposit laws.

The distribution of the number of bottles recycled shown in Table 3 is consistent with the theoretical model in which recycling behavior follows a discrete threshold rather than a continuous process. For all bottled water users, $29.1 \%$ recycle 0 bottles out of 10 , while $42.0 \%$ recycle 10 out of 10 . The next most prevalent levels of recycling are 9 and 8 bottles out of 10 , as people attempt to recycle most but not all of their bottles, perhaps because they are drinking the water in the car or at some other location. Interestingly, there is minimal clustering of responses at 5 out of 10, which one might have expected if respondents were focusing on salient numerical responses rather than attempting to assess their actual recycling amount.

Columns 2-4 in Table 3 break the sample by three recycling regime categories. The first recycling policy shown in column 3 of Table 3 is the presence of an effective recycling law but no water bottle deposit law. Such a law shifts the mass of the distribution, decreasing the percentage of respondents who indicate that they do not recycle at all, and increasing the percentage who indicate $100 \%$ recycling. As column 5 indicates, almost the entire mass shift is 
from 0 out of 10 bottles recycled to 9 or 10 bottles recycled. The addition of water bottle deposits is shown in column 4 . As the calculation of the differences in column 6 indicates, there is a negligible incremental effect of water bottle deposits except at the tails of the distribution, where the percent of those indicating zero recycling drops by 24.7 percentage points and the percent indicating complete recycling increases by 26.2 points. ${ }^{25}$

The consistent pattern across all these results is that most people adopt a recycling strategy of either being a diligent recycler or not recycling at all. The introduction of effective recycling laws or water bottle deposit laws consequently has a discontinuous effect across the distribution of recycling patterns as water bottle users shift recycling levels through a threshold transformation of behavior.

\section{Determinants of the Total Recycling Amount}

The first series of regression analyses focuses on the proportion of water bottles recycled. To demonstrate robustness across analyses, four different estimation approaches are used. The first column in Table 4 presents ordinary least squares (OLS) estimates for which we report robust heteroskedasticity-corrected standard errors. To take into account the bounded nature of the responses that cluster at 0 and 10, the second column of Table 4 presents the two-sided Tobit regression estimates. Finally, one might hypothesize that respondents were not giving precise estimates of the actual number of bottles recycled but were simply indicating their relative degree of recycling and perhaps overstating the actual number of bottles recycled. We explore

\footnotetext{
${ }^{25}$ This efficacy of water bottle deposits is consistent with Ashenmiller's (2009) finding that bottle deposit laws increase the amount of material recycled at Santa Barbara, CA redemption centers. Beatty et al. (2007) find that curbside recycling largely cannibalizes the effect of drop-off recycling centers when incomes are high or unemployment is low. Their analysis is within state for California, but if the comparison instead is with states with no effective recycling law, then the incremental effect of such recycling policies potentially may be greater. Several previous studies focused on bag/tag programs and pricing by weight programs. Reschovsky and Stone (1994), Fullerton and Kinnaman (1996), Kinnaman and Fullerton (2000), and Jenkins et al. (2003) found no statistically significant effect of unit pricing on recycling. Van Houtven and Morris (1999) found that unit pricing affected whether people recycle but not the amount of recycling.
} 
this possibility in two ways. The third column of results in Table 4 presents the ordered logit estimates, for which the three ordered categories are $0,1-7$, and 8-10 out of 10 bottles. The final column of Table 4 reports probit estimates, for which the dependent binary variable is equal to 1 if the individual recycles $1-10$ out of 10 bottles and 0 if the individual does not recycle any bottles. ${ }^{26}$ These formulations of the model address the possibility that the responses have ordinal rather than cardinal significance or are binary, indicating only whether someone is a recycler or not. ${ }^{27}$ Moreover, the categories reflect the different discontinuous recycling groupings of consumers. Because of the strong parallels across the four analyses, the discussion here focuses on the OLS estimates where the coefficients reflect the linear impact of the variable on recycling behavior.

The first pair of policy variables pertains to the state's bottle deposit laws. The deposit state variable is a 0-1 indicator variable for whether the state has a bottle deposit law. A second 0-1 variable then indicates if the deposit law covers water bottles. Both of the state deposit variables raise the number of bottles recycled. The broad deposit variable raises the number of water bottles recycled number by 0.6 out of 10 bottles, while the presence of a specific water bottle deposit law increases plastic water bottle recycling by 2.1 out of 10 bottles. Together, consumers in states with both laws recycle an additional 2.7 out of 10 bottles, controlling for all other influences, including the recycling law regime.

The next set of three variables pertains to the state recycling law. The two most stringent forms of laws—mandatory recycling and required opportunities for recycling—are combined into a single category of 14 states plus the District of Columbia because the small number of the

\footnotetext{
${ }^{26}$ Other ordered logit specifications yielded similar results. For example, treating each of the 0 to 10 responses as a separate ordered response leads to estimates that have the same signs and statistical significance as those reported here.

${ }^{27}$ Jenkins et al. (2003) also use an ordered logit approach to analyze categorical responses for recycling behavior that they collapsed into three gradations of recycling rates. Similarly, Halvorsen (2008) uses an ordered probit model.
} 
component groups makes it impossible to reject the hypothesis that the coefficients for these two categories are equal. ${ }^{28}$ These laws should have the greatest influence since they have the greatest effect on the costs of recycling as they make available low cost recycling options, and in the case of mandatory recycling, impose penalties on those who fail to recycle. Laws that require either mandatory recycling or the opportunity to recycle increase recycling by 1.9 out of every 10 bottles.

Laws that only require regional waste management plans with recycling considerations also have a significant positive effect on recycling, boosting the recycling out of 10 bottles by 0.7 bottles. This effect has a significantly smaller point estimate than of the 1.9 effect of the more stringent mandatory/opportunity recycling laws. ${ }^{29}$

The weakest of the recycling law variables is for states that have a waste reduction goal, but no required action. This variable does not have a statistically significant effect compared to the no recycling law states. ${ }^{30}$ The pattern of coefficient magnitudes is consistent with the relative stringency of the laws. Mandatory recycling and required recycling opportunity laws have the greatest effect, followed by planning laws, with no statistically significant effect of the weakest laws that are limited to specifying a waste reduction goal. Because of the significant effects on recycling of mandatory/opportunity laws and planning regimes we refer to these as the effective recycling laws.

Next we consider user demographics on recycling. Higher income levels increase the time opportunity costs of recycling. Income may also influence the value the consumer places on recycling. The effect of income on the number of bottles recycled is positive, but small,

\footnotetext{
${ }^{28}$ The F test had a value of 1.66 with a probability value of 0.1977 . Similarly, Jenkins et al. (2003) found that for plastic bottles generally, mandatory recycling had no additional effect when curbside recycling is already available. 29 The pertinent $F$ value is 32.40 , with a probability value 0.0000 .

${ }^{30}$ Planning states are more effective than goals states. The F statistic for the test for whether the planning variable coefficient equals that of the goals variable is 9.81, with a probability value of 0.0017 .
} 
suggesting that the increased opportunity costs are not sufficient to totally offset the higher amount of recycling among higher income respondents. ${ }^{31}$ Individual education has a positive effect on recycling, which serves both as a measure of the respondent's knowledge of available recycling options as well as lifetime wealth. ${ }^{32}$

The value that the respondents place on environmental quality is captured directly by whether the respondents consider themselves to be environmentalists as well as by whether the respondent is a member of a major national environmental organization. ${ }^{33}$ Each of these variables has the expected positive effect, with people who consider themselves to be environmentalists recycling an additional 1.6 out of 10 bottles, and members of environmental organizations recycling an additional 0.5 bottles after taking into account the effect of being an environmentalist and other variables.

To the extent that these environmental variables correspond to the warm glow benefit from recycling, then it is possible to monetize this effect. The water bottle deposit variable reflects the inducement of a 5 cent per bottle payment. Being a self-described environmentalist is $77 \%$ as influential, or equivalent to about a 4 cent per bottle value, while being a member of an environmental organization is $21 \%$ as effective, or a value of about 1 cent per bottle. Since environmental organization members are also self-described environmentalist, their combined warm glow benefit is 5 cents per bottle, or almost equivalent to the effect of the bottle deposit. Several of the other personal characteristic variables are influential as well. Recycling rates increase with age, are lower for African Americans, and are higher for larger households.

\footnotetext{
${ }^{31}$ Higher income respondents may also live in communities with more access to recycling options that minimize opportunity costs (income is positively correlated with curbside recycling).

${ }^{32}$ In contrast, income and education did not significantly affect plastic bottle recycling in Jenkins et al.'s (2003) study that was restricted to primarily middle and upper income groups. Collins et al. (2006) found that recycling rates increase with income in Scotland. Kinnaman (2005) found no significant effect of the percent of state residents with a high school diploma on the percent of state waste that is recycled.

${ }^{33}$ Previous studies concerned with the household's pro-environment preferences include Halvorsen's (2008) study of recycling in Norway.
} 
Recycling rates increase for homeowners, but that may reflect the greater availability of curbside recycling and convenient recycling locations for this group. The volume of recycling as measured by the dollars spent on bottled water does not have a significant effect on the percent of bottles recycled, but including this variable nevertheless serves an important role in the analysis to account for the volume of bottled water purchased. ${ }^{34}$ Otherwise, variables such as income might be capturing the quantity effect. Use of bottled water in the car does not significantly reduce recycling even though recycling may be more difficult for such users, and reusing water bottles does not affect the recycling rate.

The regional variables are influential and indicate the considerable geographic differences in recycling rates. Urban and suburban residents of metropolitan statistical areas (MSAs) recycle an additional 1.3 out of 10 additional bottles, a result consistent with the greater availability of curbside recycling and convenient recycling centers in such locales. In addition, state laws generally exempt rural areas from recycling requirements.

To explore these differences further, Appendix Table C2 reports separate regressions for the urban (MSA) and non-urban subsamples. ${ }^{35}$ The principal differences are that state deposit laws and state recycling planning requirements significantly increase plastic water bottle recycling in urban areas but not outside of these areas. Plastic water bottle deposits are equally effective in each context.

The efficacy of the policy measures in promoting recycling behavior also may vary across the populations and in different policy regimes. Table 5 reports selected coefficients from additional regressions including interactions of the policy variables and both income and whether the respondent is an environmentalist. Given a threshold model, we expect negative interactions

\footnotetext{
${ }^{34}$ The dollars spent variable remains statistically insignificant if the income variable is omitted from the equation.

${ }^{35}$ The estimated parameters from the two regressions differ statistically, with an F (32, 3094) statistic of 3.30 and a probability value of 0.0000 .
} 
between positive factors, because either one can drive one over the threshold. The negative interactive effect of income and water bottle deposit laws implies that higher income people are less likely to recycle their bottles. ${ }^{36}$ Having a water bottle deposit law also reduces the marginal effect of being an environmentalist by more than a half. ${ }^{37}$ Because environmentalists will already have an incentive to recycle without a financial inducement, bottle bills are less effective among this group. On balance, the self described environmentalists return 0.7 additional bottles out of 10 in states with bottled water deposit laws. The separate regressions for environmentalists and non-environmentalists reported in Appendix Table C2 indicate many parallels in behavior with one notable difference being that the financial inducements of general state deposit laws do not significantly boost plastic water bottle recycling for environmentalists, but are effective for non-environmentalists. ${ }^{38}$ The other interaction terms in Table 5 are not statistically significant, as the effect of the water bottle deposit variable on recycling exhibits more individual heterogeneity than do the other recycling law variables.

\section{Determinants of Curbside Recycling and Returning Bottles for Deposit}

While both recycling laws and bottle deposit laws should each increase the degree to which people recycle plastic water bottles, the composition of the recycling should differ. Laws that increase the availability of curb pickups reduce the costs of curb recycling relative to returning the bottles to a recycling center and should have a positive effect on curb recycling and a negative effect on returning bottles for deposit. Likewise, water bottle deposit laws increase the economic benefits of returning bottles for deposit, consequently increasing the likelihood of returning the bottles and decreasing the attractiveness of using curbside pickup for which there is

\footnotetext{
${ }^{36}$ The income effect pattern is consistent with Ashenmiller's (2009) finding that bottle returns are a relatively more important income source for people in lower income groups.

${ }^{37}$ A comparable interaction with being a member of an environmental organization did not have a statistically significant effect and is not included in Table 5's regressions.

${ }^{38}$ One can reject the hypothesis that the estimated parameters from the two regressions are the same, with an F (31, 3080 ) statistic of 6.21 and a probability value of 0.0000 .
} 
no payment. The analysis below tests these propositions by focusing on respondent answers to a question regarding two forms of recycling behavior over the past month. ${ }^{39}$

The probit regression for whether the respondent used curbside recycling for plastic water bottles in the past month is reported in Table 6, where all coefficients have been transformed to reflect marginal probabilities. State deposit laws generally do not significantly affect curbside recycling. Residents of states that have mandatory recycling or opportunity for recycling laws have a 0.26 higher probability of using curbside recycling for plastic water bottles, while states with recycling plans have a 0.07 higher probability of using curbside recycling than residents of states with no recycling laws. The presence of recycling goals has no statistically significant effect on use of curbside recycling. ${ }^{40}$

Many of the other patterns shown in Table 6 parallel the earlier results with respect to the number of bottles recycled. All recycling laws variables except for those restricted to recycling goals boost curbside recycling. The use of curbside recycling is an increasing function of income, education, age, whether the respondent is an environmentalist, and whether the respondent lives in a MSA.

We also interacted the various legal and policy regimes with income and whether the individual is an environmentalist. The mean interaction effect between mandatory or opportunity laws and whether the respondent is an environmentalist on curbside recycling is about 0.01 with a standard error of 0.04 and z-statistic of 0.351 . The interaction effect ranged, however, from a negative 0.04 to a positive 0.06 , with the z-statistic as high as 2.429 for some

\footnotetext{
${ }^{39}$ See Appendix Table A2 for the survey question wording.

${ }^{40}$ Kinnaman (2005) found that mandatory beverage container deposits and recycling goals do not significantly affect the availability of curbside recycling, while laws imposing curbside recycling requirements do increase the availability of curbside recycling. Additionally, he found no statistically significant effects on the availability of curbside recycling of several other laws: bans on yard waste from landfills, bans of recyclable materials from landfills, tax credits for facilities, or requirements that government agencies purchase recycled material.
} 
probability levels of using curbside recycling. ${ }^{41}$ The other interaction effects were never statistically significant.

The presence of bottle deposits for plastic water bottles should foster the returns of these bottles. Table 7 includes three sets of probit estimates for the probability that the respondent returns bottles for deposit or to the recycling center and for the two components of this probability — whether the respondent returned the bottles for deposit, presumably to a store where such bottles are purchased, and when the respondent returned the bottles to a recycling center.

The overall return probability for plastic bottles increases by 0.10 if the state is a general bottle deposit state. Since all plastic water bottle states also require deposits for other bottles, the additional 0.15 probability of bottle returns in a water bottle deposit state implies an overall 0.25 probability of returning plastic water bottles in states with water bottle deposits. Financial incentives to return bottles are effective, and the presence of other deposit requirements also boosts the return rate because there will be a greater total payoff to bottle returns. In terms of the composition of the influence, the water bottle deposit variable has a much stronger influence on returning bottles to the recycling center than it does on returning bottles for deposit. This greater marginal effect may be because returning bottles for deposit to the store does not involve additional fixed costs if a trip was already planned for shopping.

Bottles recycled at curbside will not give consumers a financial payoff, but the presence of curbside recycling in providing the environmental benefit may reduce the relative utility of returning the bottles. Indeed, for respondents in states with the strongest recycling laws that provide for mandatory recycling or the opportunity to recycle, there is a 0.04 lower probability of returning the bottles to a recycling center or for a deposit. This effect reduces the benefit of

\footnotetext{
${ }^{41}$ This analysis uses the Stata command "inteff” per Norton, Wang, and Ai (2004).
} 
water bottle deposits by about one-fourth. Recycling planning law states have a small significant negative effect on returns for deposit.

The principal demographic factors that influence deposit returns are income and whether the respondent is an environmentalist. Income has a negative effect because the time cost of bottle returns is higher and the financial gains from returning bottles for money are less consequential for those in higher income groups. Environmentalists are more likely to return the bottles for deposit. Finally, the interaction results indicate that being an environmentalist and having higher income reduces the average efficacy of water bottle deposits on returning bottles for deposit or returning bottles to a recycling center. ${ }^{42}$

\section{Effects of Law Changes}

The results indicate that recycling rates are higher in states with stringent recycling law or deposit policies. It is possible, however, that states that initiated more stringent or expansive legal measures already had many diligent recyclers, though the empirical analysis controlled for many contributing factors such as whether the person is an environmentalist. To investigate this question of causation, we take advantage of two legal changes that occurred during the administration of the survey. Specifically, Oregon and Connecticut both added water bottles to their deposit bills in 2009. The sample from these states includes 68 observations from 2008 and 37 from 2009, thus providing data on recycling behavior for Oregon and Connecticut both before and after they each implemented their expanded bottle bills. Although the sample of households experiencing changes is modest, the results are consistent with previous evidence of recycling responses to plastic water bottle deposits.

\footnotetext{
${ }^{42}$ The inteff command calculates the mean interaction effect of water deposits and being an environmentalist as -0.084 with mean standard error 0.048 and mean z-statistic -1.730 . The mean interaction effect of water deposits and having higher income is -0.007 with mean standard error 0.005 and mean z-statistic -1.285 . We also interacted water deposits with mandatory/opportunity laws but we do not report the results because the negative interaction coefficient was never statistically significant.
} 


\section{Oregon}

Oregon implemented its bottle bill expansion on January 1, 2009. The sample includes 38 individuals before the expansion and 14 individuals surveyed in October 2009, nine months after the expansion. Table 8 summarizes the bottle recycling breakdown for those two groups. After the expansion, mean water bottle recycling increased from 7.2 to 8.5 bottles out of 10 . Specifically, about $13 \%$ more people became diligent recyclers after the change. Analysis of differences in recycling rates within Oregon before and after the bottle deposit law, however, indicates that the changes are not statistically significant. ${ }^{43}$ As with the earlier results, there is a pronounced shift in the mass of the distribution from people who did not recycle at all to the diligent recycling group. Table 9 presents the difference-in-difference regression results. Although the interaction term between 2009 and Oregon has a positive coefficient, it is not statistically significant at the usual levels for the analysis of the number out of 10 bottles recycled.

The percentage of respondents who return their bottles for deposit exhibits a remarkable shift after the introduction of plastic water bottle deposits. As indicated by the data in the final column of Table 8, that percentage rises by almost 50 percent. Moreover, the difference-indifference analysis of the probability of returning bottles for deposit in Table 9 also indicates a positive and statistically significant effect of introducing plastic water bottle deposits. ${ }^{44}$

\section{$\underline{\text { Connecticut }}$}

Connecticut's bottle bill expansion was implemented on October 1, 2009. The sample included information from Connecticut residents between October 16 and October 27 in 2009,

\footnotetext{
${ }^{43}$ The t-statistic was -1.08 , with a one-sided test probability value of 0.1421 .

${ }^{44}$ The notes to Table 9 summarize the return for deposit inteff results, which are consistent with the results for the simple means tests. The decrease in the number of respondents indicating that they curb recycle was not statistically significant.
} 
resulting in $30 \mathrm{CT}$ individuals before the change and 23 individuals about two weeks after the enactment of plastic water bottle deposits. Consequently, there may not have been sufficient time for the full effects of the policy change to be manifested, as 13 of the 23 people were interviewed only two weeks after the change. Of the 23 individuals interviewed after the change, 9 of these answered questions on their recycling behavior both before and after the change.

There is evidence of substantial awareness of the policy shift as 21 out of the 23 interviewed after the change indicated that they were aware that Connecticut recently included water bottles in its deposit bill.

Table 8 summarizes the recycling behavior in Connecticut before and after the change. ${ }^{45}$ The level of recycling in CT increased from 8.0 to about 9.0 bottles out of 10, although this change was not statistically significant. ${ }^{46}$ The increase in the frequency of diligent recyclers who recycle 8-10 out of 10 bottles exceeded the increase in the non-recycling percentage.

\section{$\underline{\text { Pooled Oregon and Connecticut Experiments }}$}

Pooling the results from CT and OR increases the number of people who experienced the policy shift of the introduction of water bottle deposits. The mean increase in recycling rates shown in Table 8 is statistically significant. ${ }^{47}$ The differences-in-differences regressions for both the number of bottles recycled and whether people return bottles for deposit both indicate effects consistent with the efficacy of water bottle deposits. The regressions for the number of bottles recycled out of 10 in Table 9 yield interaction effects that exceed the estimated standard errors, and recycling rates are higher in CT and OR in 2009 in the Tobit results at about the 0.10 level,

\footnotetext{
${ }^{45}$ We also analyzed the Connecticut residents that were aware of the change and the nine individuals interviewed before and after the change. The composition of the results was similar to the composition for the overall sample from Connecticut, and also not significant, so we do not report those in Table 8.

${ }^{46}$ The t-statistic was 1.16 , with a one-sided test probability value of 0.1261 . The increase in the number of respondents indicating that they return bottles for deposit after the bottle bill extension was also not statistically significant, with a t-statistic of 0.27 and a one-sided test probability value of 0.3933 . Changes in the number of respondents indicating that they curb recycle are also not statistically significant.

${ }^{47}$ The t-statistic was 1.76, with a two-sided test probability value of 0.0806 .
} 
one-sided test. ${ }^{48}$ A much stronger indication of the efficacy of the plastic water bottle deposits is the results in Table 9 for whether the respondent returned the bottles for deposit. The interaction of the 2009 variable with the two states that introduced this policy is positive and statistically significant at the usual level.

The overall thrust of the analysis of the water bottle deposit experiments is to reinforce the implications of the earlier cross sectional results. The observed patterns of changes in recycling behavior are consistent with the efficacy of the bottle deposit policies. The statistical significance of the effects for the pooled OR and CT samples in the differences-in-differences analysis is quite striking given that only 37 members of the sample of 3,158 experienced the policy change, and 23 of these 37 are from CT, where the policy was implemented at the start of the survey month.

\section{Conclusion}

Water bottle deposits and recycling laws foster recycling efforts in different ways. The bottle deposits provide a financial inducement to recycle, while the recycling laws reduce the time costs by providing curbside recycling and convenient recycling centers. Recycling laws also may include financial penalties for noncompliance. We find both water bottle deposits and recycling laws to be effective. Moreover, the strength of effects for the recycling laws follows the degree of stringency of these measures.

The analysis of the interaction between factors testifies to the diminishing marginal efficacy of recycling incentives as predicted by a threshold model of response at the individual level. Mandatory recycling laws offer only modest recycling gains compared to planning laws. Self-described environmentalists are more likely to recycle without bottle deposits so that these

\footnotetext{
48 The probability value on the pooled Oregon and Connecticut interaction term in the reported Tobit regression is
} 0.109 . 
interventions have less effect on their recycling behavior than on less environmentally oriented respondents. For people in upper income groups, the financial inducements provided by bottle deposits are less effective, and the time costs of taking bottles to recycling centers loom large.

The central role of economic analysis in predicting the consumer response manifests perhaps most clearly in the stark pattern of individual recycling activity. For most policy interventions, one would expect modest policy impacts throughout the range of behavior. Thus, non-recyclers would become modest recyclers, and modest recyclers would become more diligent recyclers. This kind of continuous policy influence is not borne out empirically. Instead, the observed shifts reflect starker changes in behavior that are consistent with the economic structure of the recycling decision and how policies will influence this decision. Given the high fixed costs associated with recycling efforts, the hypothesis generated from rational economic behavior theory is that people will tend to gravitate toward extremes in their efforts, recycling either a few or most of their bottles. Empirically, this prediction is borne out, as there are few intermediate recyclers. Both recycling laws and bottle deposit laws have discontinuous effects on recycling behavior. In each case, the measures have a transformative effect, shifting individual consumers from not recycling at all to becoming committed recyclers. Consistent with our result that people respond in a discontinuous manner to recycling incentives, policies have their greatest effect among those who would not already choose to recycle. 


\section{References}

Ashenmiller, Bevin. 2006. "The Effect of Income on Recycling Behavior in the Presence of a Bottle Law: New Empirical Results,” working paper. . 2009. “Cash Recycling, Waste Disposal Costs, and the Incomes of the Working Poor: Evidence from California,” 85 Land Economics 539-51. . 2010. “Externalities from Recycling Laws: Evidence from Crime Rates,” 12(1) American Law and Economics Review 245-61.

Beatty, Timothy K.M., Peter Berck, and Jay P. Shimshack. 2007. “Curbside Recycling in the Presence of Alternatives,” 45 Economic Inquiry 739-55.

Bohm, Peter. 1981. Deposit-Refund Systems: Theory and Applications to Environmental, Conservation, and Consumer Policy. Published for Resources for the Future, Inc. Baltimore: Johns Hopkins University Press.

Bottle Bill Resource Guide, www.bottlebill.org/about.htm.

Callan, Scott and Janet Thomas. 1997. “The Impact of State and Local Policies on the Recycling Effort,” 23 Eastern Economic Journal 411- 24.

Collins, Alan, Richard O’Doherty, and Martin C. Snell. 2006. “Household Participation in Waste Recycling: Some National Survey Evidence from Scotland,” 49 Journal of Environmental Planning and Management 121-40.

Container Recycling Institute. 2008. “Wasting and Recycling Trends: Conclusions from CRI’s 2008 Beverage Market Data Analysis,” http://www.containerrecycling.org/assets/pdfs/reports/2008-BMDA-conclusions.pdf.

Derksen, Linda, and John Gartrell. 1993. “The Social Context of Recycling,” 58 American Sociological Review 434-42. 
Fullerton, Don, and Thomas C. Kinnaman. 1996. "Household Responses to Pricing Garbage by the Bag," 86 American Economic Review 971-83.

Gaba, Jeffrey M., and Donald W. Stever. 2008. Law of Solid Waste, Pollution Prevention and Recycling. Eagan, MN: Thomson/West.

Halvorsen, Bente. 2008. "Effects of Norms and Opportunity Cost of Time on Household Recycling,” 84 Land Economics 501-16.

Hong, Seonghoon, Richard M. Adams, and H. Alan Love. 1993. “An Economic Analysis of Household Recycling of Solid Waste: The Case Study of Portland, Oregon,” 25 Journal of Environmental Economics and Management 136-46.

Hong, Seonghoon, and Richard M. Adams. 1999. "Household Responses to Price Incentives for Recycling: Some Further Evidence,” 75 Land Economics 505-14.

Jenkins, Robin R., Salvador A. Martinez, Karen Palmer, and Michael J. Podolsky. 2003. “The Determinants of Household Recycling: A Material-Specific Analysis of Recycling Program Features and Unit Pricing,” 45 Journal of Environmental Economics and Management 294-318.

Kaufman, Scott M., Nora Goldstein, Karsten Millrath, and Nickolas J. Themelis. 2004. “The State of Garbage in America," 45 BioCycle 31-41.

Kinnaman, Thomas C. 2005. "Why do Municipalities Recycle?,” 5 Topics in Economic Analysis and Policy http://www.bepress.com/bejeap/topics/vol15/iss1/art5.

_ _ 2006. "Examining the Justification for Residential Recycling," 20 Journal of Economic Perspectives 219-32.

Kinnaman, Thomas C., and Don Fullerton. 2000. “Garbage and Recycling with Endogenous Local Policy,” 48 Journal of Urban Economics 419-42. 
Morris, Jeffrey, Bill Smith, and Rick Hlavka. 2005. "Economic and Environmental Benefits of a Deposit System for Beverage Containers in Washington State,” Prepared for City of Tacoma Solid Waste Management, http://www.containerrecycling.org/assets/pdfs/reports/2004-EconEnviroWA.pdf.

Nestor, Deborah Vaughn, and Michael J. Podolsky. 1998. “Assessing Incentive-Based Environmental Policies for Reducing Household Waste Disposal,” 16 Contemporary Economic Policy 401-12.

Norton, Edward C., Hua Wang, and Chunrong Ai. 2004. “Computing Interaction Effects and Standard Errors in Logit and Probit Models,” 4 Stata Journal 154-67.

Porter, Richard C. 1983. “Michigan’s Experience with Mandatory Deposits on Beverage Containers,” 59 Land Economics 177-94.

Reschovsky, James D., and Sarah E. Stone. 1994. “Market Incentives to Encourage Household Waste Recycling: Paying for What You Throw Away,” 13 Journal of Policy Analysis and Management 120-39.

Rodwan, Jr., John G. 2009. “Confronting Challenges: U.S. and International Bottled Water Developments and Statistics for 2008," Bottled Water Reporter 12-8.

Saltzman, Cynthia, Vijaya G. Duggal, and Mary L. Williams. 1993. "Income and the Recycling Effort: A Maximization Problem,” 15 Energy Economics 33-8.

Simmons, Phil, Nora Goldstein, Scott M. Kaufman, Nickolas J. Themelis, and James Thompson, Jr. 2006. “The State of Garbage in America,” 47 BioCycle 26-43.

Sterner, Thomas, and Heleen Bartelings. 1999. "Household Waste Management in a Swedish Municipality: Determinants of Waste Disposal, Recycling and Composting,” 13 Environmental and Resource Economics 473-91. 
Suwa, Tatsuo, and Takehiro Usui. 2007. "Estimation of Garbage Reduction and Recycling Promotion under the Containers and Packaging Recycling Law and Garbage Pricing,” 8 Environmental Economics and Policy Studies 239-54.

Tchobanoglous, George, and Frank Kreith. 2002. Handbook of Solid Waste Management, 2nd ed. New York: McGraw-Hill.

U.S. Environmental Protection Agency. 2003. “Analysis and Findings of The Gallup Organization’s Drinking Water Customer Satisfaction Survey,” Office of Groundwater and Drinking Water, http://www.epa.gov/ogwdw/ccr/pdfs/tools_survey_gallup_customersatification2003.pdf. . 2007. "Municipal Solid Waste in the United States: 2007 Facts and Figures,” http://www.epa.gov/waste/nonhaz/municipal/pubs/msw07-rpt.pdf. . 2008. “Factoids: Drinking Water and Ground Water Statistics for 2008,” Office of Water, EPA 816-K-08-004, www.epa.gov/safewater/data.

U.S. Government Accountability Office. 2009. “Bottled Water: FDA Safety and Consumer Protections Are Often Less Stringent Than Comparable EPA Protections for Tap Water, GAO-09-610,” Washington, D.C.: GAO

Van Houtven, George L., and Glenn E. Morris. 1999. “Household Behavior Under Alternative Pay-As-You-Throw Systems for Solid Waste Disposal,” 75 Land Economics 515-37. Yang, Hai-Lan, and Robert Innes. 2007. “Economic Incentives and Residential Waste Management in Taiwan: An Empirical Investigation,” 37 Environmental and Resource Economics 489-519. 
Table 1: Sample Characteristics

\begin{tabular}{|c|c|c|}
\hline & Mean & Std. Dev. \\
\hline \multicolumn{3}{|l|}{ Dependent variables } \\
\hline Number/10 plastic bottles recycled & 6.0811 & 4.3849 \\
\hline Use curb recycling & 0.4624 & 0.4987 \\
\hline Return to recycling station/for deposit & 0.2130 & 0.4095 \\
\hline Return bottles for deposit & 0.0414 & 0.1991 \\
\hline Return to recycling station & 0.1820 & 0.3859 \\
\hline \multicolumn{3}{|l|}{ State law variables } \\
\hline State has deposit law & 0.2806 & 0.4494 \\
\hline State has deposit law covering water bottles & 0.1212 & 0.3264 \\
\hline $\begin{array}{l}\text { State has mandatory recycling or provides an } \\
\text { opportunity to recycle }\end{array}$ & 0.3566 & 0.4790 \\
\hline State requires a regional recycling plan & 0.4362 & 0.4960 \\
\hline State requires a recycling goal & 0.0357 & 0.1855 \\
\hline \multicolumn{3}{|l|}{ Personal characteristics } \\
\hline Income/10,000 & 6.0633 & 4.1846 \\
\hline Highest income category (over $\$ 175,000$ ) & 0.0267 & 0.1611 \\
\hline Years of education & 13.7720 & 2.5946 \\
\hline Considers self an environmentalist & 0.4284 & 0.4949 \\
\hline Environmental organization member & 0.0817 & 0.2739 \\
\hline Age & 48.8362 & 16.2024 \\
\hline Gender: Female & 0.5189 & 0.4997 \\
\hline Race: Black & 0.1003 & 0.3005 \\
\hline Race: Asian & 0.0182 & 0.1338 \\
\hline Race: American Indian & 0.0129 & 0.1126 \\
\hline Race: Other & 0.0481 & 0.2141 \\
\hline Hispanic & 0.0953 & 0.2937 \\
\hline Household size & 2.5191 & 1.4230 \\
\hline Homeowner & 0.7654 & 0.4238 \\
\hline Married & 0.5818 & 0.4933 \\
\hline Household head & 0.8210 & 0.3834 \\
\hline Urban (lives in a MSA) & 0.8335 & 0.3726 \\
\hline Northeast & 0.1895 & 0.3920 \\
\hline South & 0.3503 & 0.4771 \\
\hline West & 0.2193 & 0.4138 \\
\hline Midwest & 0.2409 & 0.4277 \\
\hline \$/month spent on bottled water & 7.9586 & 9.8112 \\
\hline Use bottled water in car & 0.3721 & 0.4834 \\
\hline Times reuse bottles & 1.2220 & 0.2078 \\
\hline Year 2009 & 0.2603 & 0.4388 \\
\hline
\end{tabular}


Table 2: Recycling Practices by State Recycling Legal Regime ${ }^{a}$

\begin{tabular}{|c|c|c|c|c|c|c|}
\hline Group & $\begin{array}{c}\text { Mean } \\
\text { number } / 10 \\
\text { bottles } \\
\text { recycled } \\
\text { (std. dev) }\end{array}$ & $\begin{array}{l}\text { Percent of } \\
\text { respondents } \\
\text { who curb } \\
\text { recycle }\end{array}$ & $\begin{array}{c}\text { Percent of } \\
\text { respondents } \\
\text { who return } \\
\text { for deposit } \\
\text { or to } \\
\text { recycling } \\
\text { center }\end{array}$ & $\begin{array}{c}\text { Percent of } \\
\text { respondents } \\
\text { who return } \\
\text { to recycling } \\
\text { center }\end{array}$ & $\begin{array}{c}\text { Percent of } \\
\text { respondents } \\
\text { who return } \\
\text { for deposit }\end{array}$ & $\begin{array}{c}\text { Bottles } \\
\text { collected by } \\
\text { bottler }\end{array}$ \\
\hline $\begin{array}{l}\text { Full sample } \\
(\mathrm{N}=3,158)\end{array}$ & $\begin{array}{c}6.08 \\
(4.38)\end{array}$ & 46.2 & 21.3 & 18.2 & 4.1 & 1.3 \\
\hline $\begin{array}{l}\text { No effective } \\
\text { recycling } \\
\text { law and no } \\
\text { water bottle } \\
\text { deposit law } \\
(\mathrm{N}=644)\end{array}$ & $\begin{array}{c}4.30 \\
(4.47)\end{array}$ & 30.6 & 17.6 & 17.6 & 3.1 & 0.5 \\
\hline $\begin{array}{l}\text { Effective } \\
\text { recycling } \\
\text { law only } \\
(\mathrm{N}=1,696) \\
\end{array}$ & $\begin{array}{c}5.86 \\
(4.43)\end{array}$ & 48.7 & 15.4 & 15.1 & 0.7 & 1.5 \\
\hline $\begin{array}{l}\text { Both } \\
\text { effective } \\
\text { recycling } \\
\text { law and } \\
\text { water bottle } \\
\text { deposit law } \\
(\mathrm{N}=404)\end{array}$ & $\begin{array}{c}8.59 \\
(2.82)\end{array}$ & 47.5 & 49.5 & 40.1 & 14.3 & 1.5 \\
\hline
\end{tabular}

a Notes: "Effective recycling law" is either a mandatory recycling or opportunity to recycle law or a planning law. All states with a water deposit law (CA, HI, ME, OR, CT) have either a mandatory recycling or opportunity to recycle law or a planning law. 
Table 3: Percentage Distribution of Number Recycled out of 10 Bottles by Recycling Legal Regime $^{\mathrm{a}}$

\begin{tabular}{|c|c|c|c|c|c|c|}
\hline & 1 & 2 & 3 & 4 & 5 & 6 \\
\hline $\begin{array}{l}\text { Number/10 } \\
\text { bottles } \\
\text { recycled }\end{array}$ & $\begin{array}{c}\text { Full } \\
\text { sample } \\
(\%)\end{array}$ & $\begin{array}{c}\text { Neither } \\
\text { recycling } \\
\text { law nor } \\
\text { water } \\
\text { bottle } \\
\text { deposit } \\
\text { law (\%) }\end{array}$ & $\begin{array}{l}\text { Effective } \\
\text { recycling } \\
\text { law only } \\
(\%)\end{array}$ & $\begin{array}{c}\text { Effective recycling } \\
\text { law and water bottle } \\
\text { deposit law (\%) } \\
\text { (CA,HI,ME,OR,CT) }\end{array}$ & 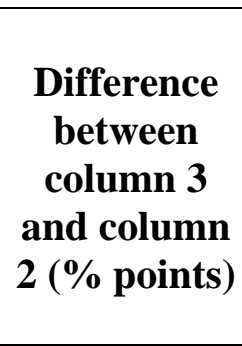 & 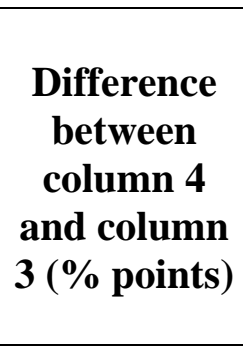 \\
\hline $\begin{array}{c}\text { Percent of } \\
\text { sample }\end{array}$ & 100 & 20.4 & 53.7 & 12.8 & & \\
\hline 0 & 29.1 & 46.4 & 31.1 & 6.4 & -15.3 & -24.7 \\
\hline 1 & 1.5 & 2.2 & 1.4 & 1.0 & -0.8 & -0.4 \\
\hline 2 & 2.4 & 2.6 & 2.7 & 0.5 & 0.1 & -2.2 \\
\hline 3 & 1.2 & 0.6 & 1.4 & 1.5 & 0.8 & 0.1 \\
\hline 4 & 1.3 & 1.2 & 1.4 & 0.5 & 0.2 & -0.9 \\
\hline 5 & 3.6 & 4.2 & 3.7 & 2.5 & -0.5 & -1.2 \\
\hline 6 & 1.7 & 1.9 & 1.4 & 2.2 & -0.5 & 0.8 \\
\hline 7 & 1.7 & 2.2 & 1.5 & 1.5 & -0.7 & 0 \\
\hline 8 & 6.6 & 6.5 & 6.6 & 6.4 & 0.1 & -0.2 \\
\hline 9 & 8.9 & 5.6 & 9.3 & 11.6 & 3.7 & 2.3 \\
\hline 10 & 42.0 & 26.6 & 39.6 & 65.8 & 13.0 & 26.2 \\
\hline Mean & $\begin{array}{l}6.00 / 10 \\
\text { bottles }\end{array}$ & $\begin{array}{l}4.30 / 10 \\
\text { bottles }\end{array}$ & $\begin{array}{l}5.86 / 10 \\
\text { bottles }\end{array}$ & $8.59 / 10$ bottles & $\begin{array}{c}1.56 \\
\text { additional/10 } \\
\text { bottles }\end{array}$ & $\begin{array}{c}2.73 \\
\text { additional/10 } \\
\text { bottles }\end{array}$ \\
\hline
\end{tabular}

a Notes: Sample size is 3,158 respondents. "Effective recycling law" is either a mandatory recycling or opportunity to recycle $(\mathrm{M} / \mathrm{O})$ law, or a planning law. All states with a water deposit law (CA, HI, ME, OR, CT) have either a M/O law or a planning law. 
Table 4: Regressions of Number of Bottles Recycled ${ }^{a}$

\begin{tabular}{|c|c|c|c|c|}
\hline & Number ou & f 10 bottles & $\begin{array}{c}\text { Ordered } \\
\text { coding } \\
(0,1-7,8-10)\end{array}$ & $\begin{array}{c}\text { Recycle at } \\
\text { all } \\
(0,1-10)\end{array}$ \\
\hline & OLS & Tobit & Ordered Logit & Probit \\
\hline State has deposit law & 0.574 & 1.741 & 0.237 & 0.084 \\
\hline & $(0.228)^{* *}$ & $(0.747)^{* *}$ & $(0.135)^{*}$ & $(0.026)^{* * *}$ \\
\hline $\begin{array}{l}\text { State has deposit law covering } \\
\text { water bottles }\end{array}$ & 2.124 & 7.721 & 1.467 & 0.194 \\
\hline & $(0.326)^{* * *}$ & $(1.199)^{* * *}$ & $(0.226)^{* * *}$ & $(0.028)^{* * *}$ \\
\hline $\begin{array}{l}\text { State has mandatory recycling } \\
\text { or provides an opportunity to } \\
\text { recycle }\end{array}$ & 1.907 & 5.919 & 1.033 & 0.169 \\
\hline & $(0.223)^{* * *}$ & $(0.708)^{* * *}$ & $(0.116)^{* * *}$ & $(0.021)^{* * *}$ \\
\hline State requires a recycling plan & 0.733 & 2.162 & 0.351 & 0.067 \\
\hline & $(0.229)^{* * *}$ & $(0.699)^{* * *}$ & $(0.114)^{* * *}$ & $(0.023)^{* * *}$ \\
\hline State requires a recycling goal & -0.467 & -1.644 & -0.166 & -0.040 \\
\hline & $(0.402)$ & $(1.307)$ & $(0.217)$ & $(0.046)$ \\
\hline Income/10,000 & 0.075 & 0.187 & 0.039 & 0.010 \\
\hline & $(0.021)^{* * *}$ & $(0.071)^{* * *}$ & $(0.012)^{* * *}$ & $(0.003)^{* * *}$ \\
\hline Highest income category & -0.509 & -1.364 & -0.278 & -0.090 \\
\hline & $(0.389)$ & $(1.472)$ & $(0.273)$ & $(0.065)$ \\
\hline Years of education & 0.149 & 0.360 & 0.106 & 0.024 \\
\hline & $(0.029)^{* * *}$ & $(0.100)^{* * *}$ & $(0.017)^{* * *}$ & $(0.004)^{* * *}$ \\
\hline Considers self environmentalist & 1.632 & 5.385 & 0.877 & 0.157 \\
\hline & $(0.146)^{* * *}$ & $(0.502)^{* * *}$ & $(0.085)^{* * *}$ & $(0.016)^{* * *}$ \\
\hline $\begin{array}{l}\text { Environmental organization } \\
\text { member }\end{array}$ & 0.456 & 1.253 & 0.380 & 0.061 \\
\hline & $(0.232)^{* *}$ & $(0.881)$ & $(0.163)^{* *}$ & $(0.032) *$ \\
\hline Age & 0.018 & 0.064 & 0.008 & 0.001 \\
\hline & $(0.005)^{* * *}$ & $(0.018)^{* * *}$ & $(0.003)^{* * *}$ & $(0.001)$ \\
\hline Female & 0.025 & 0.458 & 0.012 & -0.005 \\
\hline & $(0.140)$ & $(0.456)$ & $(0.079)$ & $(0.016)$ \\
\hline Black & -0.918 & -2.772 & -0.439 & -0.070 \\
\hline & $(0.242)^{* * *}$ & $(0.755)^{* * *}$ & $(0.127)^{* * *}$ & $(0.030)^{* *}$ \\
\hline Asian & -0.161 & -0.780 & -0.191 & 0.011 \\
\hline & $(0.432)$ & (1.616) & $(0.294)$ & $(0.072)$ \\
\hline American Indian & -0.310 & -0.748 & -0.134 & -0.027 \\
\hline & $(0.557)$ & $(1.970)$ & $(0.300)$ & $(0.063)$ \\
\hline Other & 0.083 & 0.329 & 0.088 & 0.039 \\
\hline & $(0.309)$ & $(1.038)$ & $(0.186)$ & $(0.035)$ \\
\hline Hispanic & 0.156 & 0.343 & 0.079 & 0.019 \\
\hline & $(0.240)$ & $(0.782)$ & $(0.142)$ & $(0.028)$ \\
\hline
\end{tabular}




\begin{tabular}{|l|c|c|c|c|}
\hline Household size & 0.169 & 0.506 & 0.105 & 0.018 \\
\hline & $(0.057)^{* * *}$ & $(0.182)^{* * *}$ & $(0.033)^{* * *}$ & $(0.007)^{* * *}$ \\
\hline Homeowner & 0.616 & 1.921 & 0.339 & 0.062 \\
\hline & $(0.187)^{* * *}$ & $(0.605)^{* * *}$ & $(0.104)^{* * *}$ & $(0.023)^{* * *}$ \\
\hline Married & -0.204 & -0.516 & -0.063 & -0.019 \\
\hline Household head & $(0.164)$ & $(0.533)$ & $(0.091)$ & $(0.019)$ \\
\hline & -0.233 & -0.974 & -0.121 & -0.034 \\
\hline \$/month spent on bottled water & $(0.201)$ & $(0.647)$ & $(0.109)$ & $(0.022)$ \\
\hline & 0.004 & 0.020 & 0.001 & -0.001 \\
\hline Use bottled water in car & $(0.007)$ & $(0.024)$ & $(0.004)$ & $(0.001)$ \\
\hline & -0.004 & -0.024 & -0.003 & 0.013 \\
\hline Times reuse bottles & $(0.140)$ & $(0.462)$ & $(0.079)$ & $(0.017)$ \\
\hline & -0.165 & -1.406 & -0.036 & 0.024 \\
\hline Urban (lives in a MSA) & $(0.351)$ & $(1.133)$ & $(0.195)$ & $(0.041)$ \\
\hline & 1.275 & 4.058 & 0.666 & 0.133 \\
\hline Northeast & $(0.208)^{* * *}$ & $(0.649)^{* * *}$ & $(0.110)^{* * *}$ & $(0.026)^{* * *}$ \\
\hline & 0.779 & 2.725 & 0.499 & 0.115 \\
\hline South & $(0.265)^{* * *}$ & $(0.880)^{* * *}$ & $(0.156)^{* * *}$ & $(0.026)^{* * *}$ \\
\hline & -1.043 & -3.069 & -0.503 & -0.082 \\
\hline West & $(0.199)^{* * *}$ & $(0.615)^{* * *}$ & $(0.100)^{* * *}$ & $(0.021)^{* * *}$ \\
\hline & -0.402 & -1.489 & -0.271 & -0.036 \\
\hline Year 2009 & $(0.275)$ & $(0.872)^{*}$ & $(0.148)^{*}$ & $(0.032)$ \\
\hline & 0.114 & 0.398 & 0.075 & 0.007 \\
\hline Constant & $(0.160)$ & $(0.528)$ & $(0.091)$ & $(0.019)$ \\
\hline & -0.576 & -11.013 & & \\
\hline & $(0.740)$ & $(2.460)^{* * *}$ & & \\
\hline
\end{tabular}

a Notes: * Significant at the $10 \%$ level; ** significant at the 5\% level; *** significant at the $1 \%$ level; robust standard errors in parentheses for the OLS, Ordered Logit, and Probit regressions; standard errors in parentheses for the Tobit regression. R squared $=0.24$ for OLS regression. Probit coefficients have been transformed to correspond to marginal effects. The regressions also include dummy variables for missing data for environmentalist, environmental organization membership, and times reuse bottles. These variables were not statistically significant in the equations. Sample size $=3,158$. 
Table 5: Regressions of Number of Bottles Recycled Including Interaction Effects ${ }^{\mathrm{a}}$

\begin{tabular}{|l|c|}
\hline & $\begin{array}{c}\text { Number out of 10 } \\
\text { bottles, OLS }\end{array}$ \\
\hline State has deposit law & 0.571 \\
\hline & $(0.229)^{* *}$ \\
\hline State has deposit law covering water bottles & $(0.6389)^{* * *}$ \\
\hline & 2.345 \\
\hline $\begin{array}{l}\text { State has mandatory recycling or provides an opportunity to } \\
\text { recycle }\end{array}$ & $(0.410)^{* * *}$ \\
\hline & 0.589 \\
\hline State requires a recycling plan & $0.416)$ \\
\hline & -0.431 \\
\hline State requires a recycling goal & $(0.407)$ \\
\hline & 0.110 \\
\hline Income/10,000 & $(0.040)^{* * *}$ \\
\hline & 1.825 \\
\hline Considers self environmentalist & $(0.349)^{* * *}$ \\
\hline & -0.137 \\
\hline State with deposit law covering water bottles x Income/1,000 & $(0.042)^{* * *}$ \\
\hline $\begin{array}{l}\text { State with deposit law covering water bottles x Considers } \\
\text { self environmentalist }\end{array}$ & -1.165 \\
\hline $\begin{array}{l}\text { State has mandatory recycling or provides an opportunity to } \\
\text { recycle x Income/1,000 }\end{array}$ & $(0.357)^{* * *}$ \\
\hline & -0.045 \\
\hline $\begin{array}{l}\text { State has mandatory recycling or provides an opportunity to } \\
\text { recycle x Considers self environmentalist }\end{array}$ & $(0.044)$ \\
\hline & -0.388 \\
\hline State requires a recycling plan x Income/1,000 & $(0.407)$ \\
\hline $\begin{array}{l}\text { State requires a recycling plan x Considers self } \\
\text { environmentalist }\end{array}$ & 0.005 \\
\hline & $(0.048)$ \\
\hline
\end{tabular}

${ }^{a}$ Notes: * Significant at the $10 \%$ level; ** significant at the $5 \%$ level; *** significant at the $1 \%$ level; robust standard errors in parentheses for the OLS regression. $\mathrm{R}$ squared $=0.24$. The regression also includes all of the other variables listed in Table 4, as well as dummy variables for missing data for environmentalist, environmental organization membership, and times reuse bottles. These variables were not statistically significant in the equations. Sample size $=3,158$. 
Table 6: Probit Regressions of Use of Curbside Recycling ${ }^{\mathrm{a}}$

\begin{tabular}{|c|c|}
\hline & Use curbside recycling \\
\hline \multirow[t]{2}{*}{ State has deposit law } & 0.019 \\
\hline & $(0.032)$ \\
\hline \multirow[t]{2}{*}{ State has deposit law covering water bottles } & 0.019 \\
\hline & $(0.048)$ \\
\hline \multirow[t]{2}{*}{$\begin{array}{l}\text { State has mandatory recycling or provides an } \\
\text { opportunity to recycle }\end{array}$} & 0.257 \\
\hline & $(0.029)^{* * *}$ \\
\hline \multirow[t]{2}{*}{ State requires a recycling plan } & 0.068 \\
\hline & $(0.030)^{* *}$ \\
\hline \multirow[t]{2}{*}{ State requires a recycling goal } & -0.089 \\
\hline & $(0.058)$ \\
\hline \multirow[t]{2}{*}{ Income/10,000 } & 0.016 \\
\hline & $(0.003)^{* * *}$ \\
\hline \multirow[t]{2}{*}{ Highest income category } & -0.044 \\
\hline & $(0.061)$ \\
\hline \multirow[t]{2}{*}{ Years of education } & 0.026 \\
\hline & $(0.004) * * *$ \\
\hline \multirow{2}{*}{ Considers self environmentalist } & 0.120 \\
\hline & $(0.020)^{* * *}$ \\
\hline \multirow[t]{2}{*}{ Environmental organization member } & 0.060 \\
\hline & $(0.038)$ \\
\hline \multirow[t]{2}{*}{ Age } & 0.002 \\
\hline & $(0.001)^{* *}$ \\
\hline \multirow[t]{2}{*}{ Female } & -0.026 \\
\hline & $(0.019)$ \\
\hline \multirow[t]{2}{*}{ Black } & -0.118 \\
\hline & $(0.031) * * *$ \\
\hline \multirow[t]{2}{*}{ Asian } & -0.049 \\
\hline & $(0.064)$ \\
\hline \multirow[t]{2}{*}{ American Indian } & -0.082 \\
\hline & $(0.072)$ \\
\hline \multirow[t]{2}{*}{ Other } & 0.044 \\
\hline & $(0.043)$ \\
\hline \multirow[t]{2}{*}{ Hispanic } & 0.034 \\
\hline & $(0.032)$ \\
\hline \multirow[t]{2}{*}{ Household size } & 0.011 \\
\hline & $(0.008)$ \\
\hline \multirow[t]{2}{*}{ Homeowner } & 0.051 \\
\hline & $(0.025)^{* *}$ \\
\hline \multirow[t]{2}{*}{ Married } & -0.036 \\
\hline & $(0.022)$ \\
\hline
\end{tabular}




\begin{tabular}{|l|c|}
\hline Household head & -0.039 \\
\hline \$/month spent on bottled water & $(0.028)$ \\
\hline & -0.001 \\
\hline Use bottled water in car & $(0.001)$ \\
\hline & -0.008 \\
\hline Times reuse bottles & $(0.019)$ \\
\hline & -0.052 \\
\hline Urban (lives in a MSA) & $(0.047)$ \\
\hline & 0.295 \\
\hline Northeast & $(0.023)^{* * *}$ \\
\hline & 0.055 \\
\hline & $(0.037)$ \\
\hline Weuth & -0.131 \\
\hline & $(0.025)^{* * *}$ \\
\hline Year 2009 & -0.130 \\
\hline & $(0.035)^{* * *}$ \\
\hline
\end{tabular}

${ }^{a}$ Notes: * Significant at the $10 \%$ level; ** significant at the $5 \%$ level; *** significant at the $1 \%$ level; robust standard errors in parentheses. Coefficients have been transformed to reflect marginal effects. The regression also includes dummy variables for missing data for environmentalist, environmental organization membership, and times reuse bottles. Sample size $=3,158$. 
Table 7: Probit Regressions of Recycling Behaviors ${ }^{a}$

\begin{tabular}{|c|c|c|c|}
\hline & $\begin{array}{c}\text { Return to } \\
\text { recycling center } \\
\text { or for deposit }\end{array}$ & $\begin{array}{c}\text { Return for } \\
\text { deposit }\end{array}$ & $\begin{array}{c}\text { Return to } \\
\text { recycling center }\end{array}$ \\
\hline \multirow[t]{2}{*}{ State has deposit law } & 0.102 & 0.104 & -0.005 \\
\hline & $(0.026)^{* * *}$ & $(0.019)^{* * *}$ & $(0.023)$ \\
\hline \multirow[t]{2}{*}{$\begin{array}{l}\text { State has deposit law covering water } \\
\text { bottles }\end{array}$} & 0.153 & 0.020 & 0.174 \\
\hline & $(0.043)^{* * *}$ & $(0.014)$ & $(0.043)^{* * *}$ \\
\hline \multirow[t]{2}{*}{$\begin{array}{l}\text { State has mandatory recycling or provides } \\
\text { an opportunity to recycle }\end{array}$} & -0.040 & -0.008 & -0.019 \\
\hline & $(0.022)^{*}$ & $(0.005)$ & $(0.021)$ \\
\hline \multirow[t]{2}{*}{ State requires a recycling plan } & 0.013 & -0.012 & 0.028 \\
\hline & $(0.023)$ & $(0.006)^{*}$ & $(0.022)$ \\
\hline \multirow[t]{2}{*}{ State requires a recycling goal } & -0.049 & -0.006 & -0.028 \\
\hline & $(0.037)$ & $(0.010)$ & $(0.036)$ \\
\hline \multirow[t]{2}{*}{ Income/10,000 } & -0.006 & -0.001 & -0.004 \\
\hline & $(0.002)^{* * *}$ & $(0.001)$ & $(0.002)^{*}$ \\
\hline \multirow[t]{2}{*}{ Highest income category } & -0.015 & -0.004 & -0.020 \\
\hline & $(0.046)$ & $(0.011)$ & $(0.042)$ \\
\hline \multirow[t]{2}{*}{ Years of education } & -0.002 & -0.002 & 0.000 \\
\hline & $(0.003)$ & $(0.001)^{*}$ & $(0.003)$ \\
\hline \multirow[t]{2}{*}{ Considers self environmentalist } & 0.063 & 0.003 & 0.055 \\
\hline & $(0.016)^{* * *}$ & $(0.004)$ & $(0.015)^{* * *}$ \\
\hline \multirow[t]{2}{*}{ Environmental organization member } & 0.023 & 0.001 & 0.035 \\
\hline & $(0.029)$ & $(0.007)$ & $(0.027)$ \\
\hline \multirow[t]{2}{*}{ Age } & -0.001 & -0.000 & -0.000 \\
\hline & $(0.001)$ & $(0.000)^{* *}$ & $(0.001)$ \\
\hline \multirow[t]{2}{*}{ Female } & -0.015 & -0.008 & -0.008 \\
\hline & $(0.015)$ & $(0.004)^{* *}$ & $(0.014)$ \\
\hline \multirow[t]{2}{*}{ Black } & -0.046 & 0.009 & -0.047 \\
\hline & $(0.022)^{* *}$ & $(0.009)$ & $(0.020)^{* *}$ \\
\hline \multirow[t]{2}{*}{ Asian } & 0.060 & -0.010 & 0.069 \\
\hline & $(0.051)$ & $(0.006)$ & $(0.050)$ \\
\hline \multirow[t]{2}{*}{ American Indian } & -0.050 & 0.007 & -0.042 \\
\hline & $(0.051)$ & $(0.022)$ & $(0.046)$ \\
\hline \multirow[t]{2}{*}{ Other } & 0.012 & 0.017 & -0.012 \\
\hline & $(0.032)$ & $(0.011)$ & $(0.029)$ \\
\hline
\end{tabular}




\begin{tabular}{|l|c|c|c|}
\hline Hispanic & -0.016 & -0.007 & 0.005 \\
\hline & $(0.023)$ & $(0.004)$ & $(0.022)$ \\
\hline Household size & 0.005 & 0.001 & 0.003 \\
\hline Homeowner & $0.006)$ & $(0.001)$ & $(0.005)$ \\
\hline & 0.037 & 0.001 & 0.018 \\
\hline Married & $(0.018)^{* *}$ & $(0.004)$ & $(0.017)$ \\
\hline & -0.004 & 0.001 & -0.007 \\
\hline Household head & $(0.017)$ & $(0.004)$ & $(0.016)$ \\
\hline & 0.004 & 0.001 & -0.001 \\
\hline \$/month spent on bottled water & $(0.021)$ & $(0.005)$ & $(0.019)$ \\
\hline & 0.000 & -0.000 & 0.000 \\
\hline Use bottled water in car & $(0.001)$ & $(0.000)$ & $(0.001)$ \\
\hline & 0.025 & 0.001 & 0.030 \\
\hline Times reuse bottles & $(0.015)^{*}$ & $(0.004)$ & $(0.014)^{* *}$ \\
\hline & -0.004 & 0.005 & -0.007 \\
\hline Urban (lives in a MSA) & $(0.035)$ & $(0.009)$ & $(0.033)$ \\
\hline & -0.108 & 0.004 & -0.117 \\
\hline Northeast & $(0.023)^{* * *}$ & $(0.005)$ & $(0.022)^{* * *}$ \\
\hline & 0.034 & -0.001 & 0.018 \\
\hline South & $(0.031)$ & $(0.008)$ & $(0.029)$ \\
\hline & 0.011 & -0.004 & 0.009 \\
\hline West & $(0.021)$ & $(0.007)$ & $(0.020)$ \\
\hline & 0.072 & -0.006 & 0.069 \\
\hline Year 2009 & $(0.031)^{* *}$ & $(0.007)$ & $(0.029)^{* *}$ \\
\hline & 0.013 & 0.003 & 0.012 \\
\hline & $(0.017)$ & $(0.005)$ & $(0.016)$ \\
\hline
\end{tabular}

a Notes: * Significant at the $10 \%$ level; ** significant at the $5 \%$ level; *** significant at the $1 \%$ level; robust standard errors in parentheses. Coefficients have been transformed to reflect the marginal effects on the probability of returns. The regressions also include dummy variables for missing data for environmentalist, environmental organization membership, and times reuse bottles. Sample size $=3,158$. 
Table 8: Percentage Distribution of Number Recycled out of 10 Bottles for Oregon and Connecticut Before and After the Inclusion of Water Bottles to the Bottle Bill

\begin{tabular}{|c|c|c|c|c|c|c|}
\hline & \multicolumn{5}{|c|}{ Number out of every 10 bottles recycled } & \multirow{2}{*}{$\begin{array}{c}\text { Percent Who } \\
\text { Return for } \\
\text { Deposit }\end{array}$} \\
\hline & Raw \# & $\mathbf{0}$ & $1-7$ & 8-10 & $\begin{array}{c}\text { Mean } \\
\text { (Std. Dev) }\end{array}$ & \\
\hline Full sample (\%) & 100 & 29.1 & 13.4 & 57.5 & $\begin{array}{c}6.08 \\
(4.38)\end{array}$ & 4.1 \\
\hline $\begin{array}{c}\text { Oregon before water } \\
\text { deposits }\end{array}$ & 38 & 15.8 & 18.4 & 65.8 & $\begin{array}{c}7.24 \\
(3.99)\end{array}$ & 15.8 \\
\hline $\begin{array}{c}\text { Oregon after water } \\
\text { deposits }\end{array}$ & 14 & 0 & 21.3 & 78.5 & $\begin{array}{c}8.50 \\
(2.88)\end{array}$ & 64.3 \\
\hline $\begin{array}{l}\text { Connecticut before } \\
\text { water deposits }\end{array}$ & 30 & 3.3 & 20 & 76.7 & $\begin{array}{c}8.00 \\
(3.05)\end{array}$ & 6.7 \\
\hline $\begin{array}{l}\text { Connecticut after } \\
\text { water deposits }\end{array}$ & 23 & 8.7 & 0 & 91.3 & $\begin{array}{c}8.96 \\
(2.88)\end{array}$ & 8.7 \\
\hline $\begin{array}{c}\text { Connecticut and } \\
\text { Oregon (pooled) } \\
\text { before }\end{array}$ & 68 & 10.3 & 19.1 & 70.6 & $\begin{array}{c}7.57 \\
(3.60)\end{array}$ & 11.8 \\
\hline $\begin{array}{l}\text { Connecticut and } \\
\text { Oregon (pooled) after }\end{array}$ & 37 & 5.4 & 8.1 & 86.5 & $\begin{array}{c}8.78 \\
(2.85)\end{array}$ & 29.7 \\
\hline
\end{tabular}


Table 9: Difference-in-Difference Regressions on Oregon and Oregon/Connecticut Pooled Samples $^{\mathrm{a}}$

\begin{tabular}{|c|c|c|c|c|c|c|}
\hline & \multicolumn{2}{|c|}{$\begin{array}{l}\text { Number out of } 10 \\
\text { bottles, Oregon }\end{array}$} & \multicolumn{2}{|c|}{$\begin{array}{l}\text { Number out of } 10 \\
\text { bottles, Oregon and } \\
\text { Connecticut (pooled) }\end{array}$} & \multicolumn{2}{|c|}{$\begin{array}{c}\text { Return for Deposit } \\
\text { Probit }\end{array}$} \\
\hline & OLS & Tobit & OLS & Tobit & Oregon & $\begin{array}{c}\text { Oregon/ } \\
\text { Connecticut } \\
\text { (pooled) }\end{array}$ \\
\hline \multicolumn{7}{|l|}{ State } \\
\hline \multirow[t]{2}{*}{ OR } & 1.251 & 5.330 & & & 0.123 & \\
\hline & $(0.646)^{*}$ & $(2.497) * *$ & & & $(0.060) * * *$ & \\
\hline \multirow[t]{2}{*}{$\begin{array}{l}\text { OR and } \\
\text { CT } \\
\text { (pooled) }\end{array}$} & & & 1.684 & 6.023 & & 0.084 \\
\hline & & & $(0.444) * * *$ & $(1.868)^{* * *}$ & & $(0.040)^{* * *}$ \\
\hline \multirow[t]{2}{*}{ Year 2009} & 0.275 & 0.907 & 0.227 & 0.694 & 0.002 & 0.001 \\
\hline & $(0.180)$ & $(0.605)$ & $(0.183)$ & $(0.610)$ & $(0.008)$ & $(0.008)$ \\
\hline \multicolumn{7}{|l|}{ Interaction } \\
\hline \multirow[t]{2}{*}{$\begin{array}{l}\text { OR x } \\
\text { Year } \\
2009 \\
\end{array}$} & 0.988 & 4.976 & & & 0.298 & \\
\hline & (0.995) & (5.105) & & & $(0.158)^{* * *}$ & \\
\hline \multirow[t]{2}{*}{$\begin{array}{l}\text { OR and } \\
\text { CT x } \\
\text { Year } \\
2009 \\
\end{array}$} & & & 0.763 & 5.446 & & 0.085 \\
\hline & & & $(0.669)$ & $(3.397)$ & & $(0.063) * *$ \\
\hline \multirow[t]{2}{*}{ Constant } & 5.986 & 7.463 & 5.958 & 7.373 & & \\
\hline & $(0.092)^{* * *}$ & $(0.308) * * *$ & $(0.092)^{* * *}$ & $(0.308)^{* * *}$ & & \\
\hline
\end{tabular}

${ }^{\text {a }}$ Notes: * Significant at the $10 \%$ level; ** significant at the $5 \%$ level; *** significant at the $1 \%$ level; robust standard errors in parentheses for the OLS regression. Probit coefficients have been transformed have been transformed to reflect the marginal effects on the probability of returns. The mean inteff results are 0.483 (interaction), 0.141 (standard error), and 3.420 (z-statistic) for the Oregon probit regression, and they are 0.169 (interaction), 0.084 (standard error), and 2.018 (z-statistic) for the Oregon and Connecticut (pooled) probit regression. Sample size = 3,158. 


\section{Appendix A. Sample Characteristics and Survey Questions}

Appendix Table A1: Comparison of KN Sample to the National Adult Population ${ }^{\mathrm{a}}$

Demographic Variable

Gender

Male

Female

Age

18 - 24 years old

25 - 34 years old

35 - 44 years old

45 - 54 years old

55 - 64 years old

64 - 74 years old

75 years old or older

Educational Attainment

Less than HS

HS Diploma or higher

Bachelor or higher

Race / Ethnicity

White

Black/African-American

American Indian or Alaska Native

Asian/Pacific Islander/Other

Hispanic

\section{Marital Status}

Married

Single (never married)

Divorced

Widowed

\section{Household Income}

Less than $\$ 15,000$

$\$ 15,000$ to $\$ 24,999$

$\$ 25,000$ to $\$ 34,999$

$\$ 35,000$ to $\$ 49,999$

$\$ 50,000$ to $\$ 74,999$

$\$ 75,000$ or more

$\begin{array}{cccc}\begin{array}{c}\text { US Adult } \\ \text { Population }\end{array} & \begin{array}{c}\text { Survey } \\ \text { Participants } \\ (\mathbf{n}=5,213)\end{array} & \begin{array}{c}\text { Bottled } \\ \text { Water Users } \\ (\mathbf{n}=3,158)\end{array} & \begin{array}{c}\text { Do Not Use } \\ \text { Bottled Water } \\ (\mathbf{n}=2,055)\end{array} \\ \text { Percent } & \text { Percent } & \text { Percent } & \text { Percent }\end{array}$

48.4

51.6

48.1

51.9

44.2

55.8

54.1

45.9

12.6

17.9

7.9

8.7

6.7

13.6

14.9

11.5

18.8

19.1

21.0

16.2

21.1

20.6

22.1

19.6

14.8

12.0

19.7

22.0

8.7

5.8

10.3

14.6

7.7

3.4

9.5

14.2

11.1

60.0

10.1

12.6

58.8

29.0

59.7

60.4

26.9

30.2

27.0

81.3

11.7

81.9

79.6

85.3

10.0

11.5

7.8

2.4

1.3

1.4

1.1

4.6

6.6

7.4

5.6

13.5

9.5

10.3

8.3

55.0

58.2

60.9

54.1

26.0

21.4

20.9

22.2

10.4

12.6

11.5

14.4

6.4

5.5

4.5

7.0

13.3

11.5

9.1

15.2

11.6

10.7

9.8

8.6

11.6

10.4

9.1

12.4

14.2

16.8

16.0

18.0

20.8

22.6

18.1

32.0

30.8

24.6

${ }^{a}$ U. S. Census Bureau (http://www.census.gov/). 2008 adult population (18 years+). 


\section{Appendix Table A2: Survey Questions Pertaining to Bottled Water}

\section{WELCOME.}

Welcome to our survey on the value of drinking water quality. This survey was put together by researchers at Vanderbilt and Duke Universities to help the government understand your views on the value of drinking water quality. The survey should take less than half an hour to complete, and you may stop at any time.

We hope that you will find this survey interesting. Thanks very much for your responses.

For most of the questions in this survey, there are no right or wrong answers. We are simply interested in your opinions.

\section{HHSIZE.}

How many members of your family (spouse, children, parents, or other relatives) currently live in your home, including yourself?

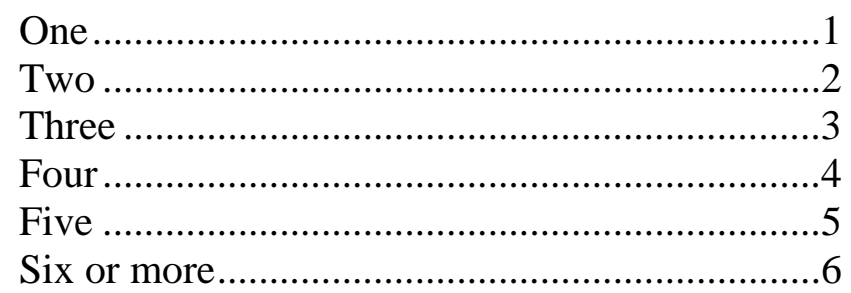

[SHOW IF HHSIZE = 1 OR REFUSED]

FAM2A.

For the rest of this survey, when a question refers to your family or members of your family who live in your home, think of it as referring only to you.

\section{[SHOW IF HHSIZE > 1]}

FAM2B.

For the rest of this survey, when a question refers to you, think of it as referring to you and the members of your family who currently live in your home. 


\section{REMEDY4.}

Do you use bottled water? (distilled, filtered, or spring water bought in small bottles, gallon jugs, or a water cooler)

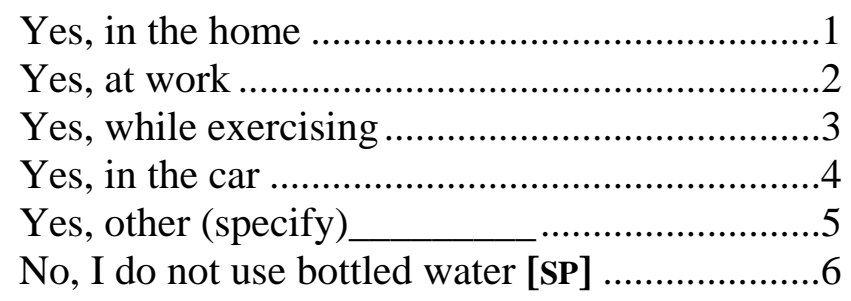

\section{[ASK IF REMEDY4=1 - 5: ANY YES ANSWER]}

\section{EXPENSE1.}

How much would you estimate that your household spends each month on bottled water?

$\$ 1$ or Less .......................................................... 1

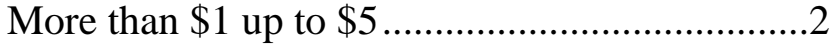

More than $\$ 5$ up to $\$ 10$........................................

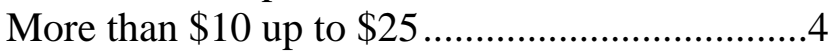

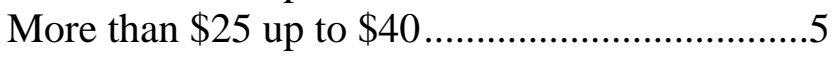

Over $\$ 40$ per month ..........................................6

Don’t Know .................................................... 7

\section{[ASK IF REMEDY4=1 - 5: ANY YES ANSWER]}

\section{BOTKIND1.}

When you drink bottled water, what kind do you most often use?

Filtered water

Spring water

Distilled water

Other (specify___

Don't know 
[ASK IF REMEDY4=1 - 5: ANY YES ANSWER]

BOTKIND2.

How do you most often buy your bottled water?

Single serving bottles

Gallon jugs

Containers larger than one gallon

[ASK IF REMEDY4=1 - 5: ANY YES ANSWER]

BOTBUY.

In the last month, what kinds of bottled water have you purchased?

Plastic bottles ........................................................

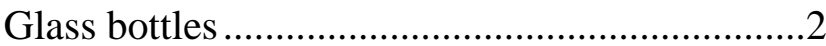

Plastic gallon jugs ..................................................

Water cooler containers ........................................

Other (specify)__ _ .........................................

\section{[ASK IF BOTBUY=1]}

BOTRECP.

In the last month, have you recycled your empty plastic water bottles using...

Curbside recycling .................................................

Take recycling to a recycling station ....................2

Return bottles for deposit.....................................

Bottler collects empty bottles when

new ones are delivered ......................................

I have not recycled plastic bottles .........................

\section{[ASK IF BOTBUY=2]}

\section{BOTRECG.}

In the last month, have you recycled your empty glass bottles using...

Curbside recycling ..............................................1

Take recycling to a recycling station ....................2

Return bottles for deposit......................................

Bottler collects empty bottles when new ones are delivered ......................................4

I have not recycled glass bottles ...........................5 


\section{[ASK IF BOTBUY=3]}

\section{BOTRECJ.}

In the last month, have you recycled your empty plastic gallon jugs using...

Curbside recycling ..............................................1

Take recycling to a recycling station ....................2

Return bottles for deposit....................................3

Bottler collects empty bottles when new ones are delivered .....................................4

I have not recycled plastic gallon jugs

\section{[ASK IF BOTBUY $=4$ ]}

\section{BOTRECW.}

In the last month, have you recycled your empty water cooler containers using...

Curbside recycling .1

Take recycling to a recycling station ....................2

Return bottles for deposit......................................

Bottler collects empty bottles when new ones are delivered ....................................4

I have not recycled water cooler containers 5

[ASK IF BOTRECP=3]

BOTDEPP.

How much money (in cents) per plastic bottle do you get for returning them for deposit? cents

[ASK IF BOTRECG $=3$ ]

BOTDEPG.

How much money (in cents) per glass bottle do you get for returning them for deposit? cents

\section{[ASK IF BOTRECJ=3]}

\section{BOTDEPJ.}

How much money (in cents) per plastic gallon jugs do you get for returning them for deposit? cents 
[ASK IF BOTRECW=3]

BOTDEPW.

How much money (in cents) per water cooler container do you get for returning them for deposit? cents

[ASK IF BOTBUY=1]

BOT10P.

Out of every 10 plastic bottles, how many would you say that you recycled or returned for reuse?

[ASK IF BOTBUY=2]

BOT10G.

Out of every 10 glass bottles, how many would you say that you recycled or returned for reuse?

\section{[ASK IF BOTBUY=3]}

\section{BOT10J.}

Out of every 10 plastic gallon jugs, how many would you say that you recycled or returned for reuse?

\section{[ASK IF BOTBUY=4]}

\section{BOT10W.}

Out of every 10 water cooler containers, how many would you say that you recycled or returned for reuse?

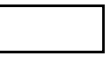

[ASK IF BOTBUY $=1$ ]

BOTREUSE.

How often do you re-fill your plastic water bottles using tap water or filtered water?

Never.

Rarely (1-2 out of every 10 bottles) ..................................

Sometimes (3-4 out of every 10 bottles)............................

Often (refill half or more of your bottles) .......................... 


\section{RECYCLE.}

Consider all of the recyclable materials that you use. Relative to your neighbors, would you say you recycle ...

\begin{tabular}{|c|c|c|c|c|}
\hline $\begin{array}{c}\text { Much Less } \\
\text { Of my } \\
\text { Recyclables }\end{array}$ & $\begin{array}{c}\text { Less } \\
\text { Of my } \\
\text { Recyclables }\end{array}$ & $\begin{array}{c}\text { About the } \\
\text { Same as my } \\
\text { Neighbors }\end{array}$ & $\begin{array}{c}\text { More } \\
\text { Of my } \\
\text { Recyclables }\end{array}$ & $\begin{array}{c}\text { Much More } \\
\text { Of my } \\
\text { Recyclables }\end{array}$ \\
\hline & & & & \\
\hline
\end{tabular}

[ASK IF STATE $=$ CT]

AWARE.

Were you aware that Connecticut recently changed its bottle deposit law to include a 5 cent deposit on plastic water bottles?

Yes $\quad 1$

No 2

\section{GREEN1.}

Would you describe yourself as an environmentalist?

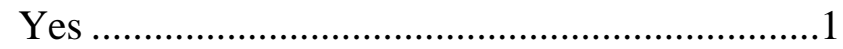

No...................................................................2

\section{ENVORG.}

Are you a member of any of the following organizations?

Environmental Defense Fund ............................1

Greenpeace......................................................2

National Audubon Society .................................3

National Wildlife Federation ............................4

Nature Conservancy ..........................................5

Natural Resources Defense Council ..................6

Sierra Club .................................................... 7

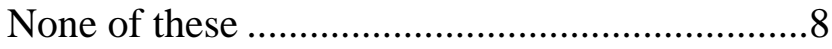




\section{Appendix B: Bottle Deposit Laws and State Recycling Laws}

Concerns about diminishing landfill space have prompted many states to pass legislation encouraging recycling. ${ }^{49}$ States with the highest disposal fees and limited amounts of disposal capacity remaining were the first to pass waste reduction legislation. The legislation has taken various forms in different states; states have set waste reduction goals, required comprehensive local planning, adopted disposal bans, enacted mandatory provisions for source separation and curbside recycling, and required refundable deposits on containers.

\section{Bottle Deposit Laws}

A bottle deposit bill, or container deposit law, requires a refundable deposit on beverage containers, usually about 5 to 10 cents, and encourages consumers to return these containers for recycling to receive their deposit back. ${ }^{50}$ As of 2009, eleven states-California, Connecticut, Delaware, Hawaii, Iowa, Maine, Massachusetts, Michigan, New York, Oregon, and Vermonthave bottle deposit laws. These states represent $29 \%$ of the U.S. population and $28 \%$ of our sample. In our survey, five of these states-California, Connecticut, Hawaii, Maine, and Oregon—included deposits on bottled water in their regulatory scheme. ${ }^{51}$ Most states have a modest 5 cent deposit on beverages; only Michigan has a 10 cent deposit on all covered beverages. Six states retain the unredeemed deposits, which provide state revenue in the millions. ${ }^{52}$ Many states without bottle deposit bills are contemplating such legislation. Seven states considered new deposit bills and three states considered updates to their existing deposit

\footnotetext{
${ }^{49}$ For discussion of the legal and policy context for the emergence of recycling laws see Tchobanoglous and Kreith (2002) and Gaba and Stever (2008).

${ }^{50}$ The exact deposit system can vary from state to state. The Bottle Bill Resource Guide, www.bottlebill.org/about.htm, provides information on each state's bottle bill.

${ }^{51}$ Connecticut's addition of bottled water to its bottle deposit scheme was implemented on October 1, 2009. New York had already passed a bill that would add bottled water, but a court order delayed implementation of this bill until October 30, 2009, which was after the final round of the survey used for this paper.

52 This statistic includes Michigan, which has a mixed system, but does not include New York, which passed a bill that would create a mixed system, but implementation of this bill was delayed to past the scope of this paper.
} 
bills in 2009. ${ }^{53}$ Connecticut and New York both passed updated bills allowing the state to retain unredeemed deposits. ${ }^{54}$ While Connecticut's update has already been implemented, New York's update has been delayed by a court ruling. ${ }^{55}$ The seven states with new deposit bill proposals were Florida, New Hampshire, New Jersey, New Mexico, North Carolina, Tennessee, and West Virginia. Most of these state bills proposed bottle deposits of at least 10 cents—with Florida's bill proposing 20 to 30 cent deposits. ${ }^{56}$ Florida's bill is the only bill to propose that bottlers retain unclaimed deposits; the rest proposed that the state retains unredeemed deposits. ${ }^{57}$ All proposed laws, except New Hampshire’s, would cover water bottles.

\section{$\underline{\text { State Recycling Laws }}$}

State laws that mandate source separation and recycling or ban disposal of certain materials in almost all municipalities were especially popular in the late 1980s and early 1990s. Many of these laws require all municipalities, counties, or cities to establish pick-up of separated materials at curbside or other convenient locations. ${ }^{58}$ These kinds of programs are usually implemented at the municipality or county level, ${ }^{59}$ but statewide recycling initiatives are also possible. For example, Pennsylvania requires all municipalities with more than 5,000 people to offer curbside recycling. In 2004, there were 974 curbside recycling programs in Pennsylvania,

\footnotetext{
${ }^{53}$ Maryland only considered setting up a task force to study the possibility of a bottle deposit, so it was not included in this statistic.

${ }^{54}$ New York's bill would also add water bottles to its list of bottles covered by the deposit.

${ }^{55}$ Confessore, Nicholas. Bottle Bill, Bottled Up, City Room, N.Y. Times (May 27, 2009), available at http://cityroom.blogs.nytimes.com/2009/05/27/bottle-bill-bottled-up/?scp=1b\&sq=bottle+deposit+new+york\&st=nyt.

${ }^{56}$ Only Tennessee and one West Virginia bill proposed 5 cent deposits.

${ }^{57}$ New Jersey's bill proposed a mixed retention plan, where the state retains 75 percent of the unredeemed deposits.

${ }^{58}$ Kinnaman $(2005$, 2006) finds that about 18 to 22 states mandate curbside recycling. Because we did not have this information for 2008, we group states with comprehensive statewide recycling provisions with those with mandatory curbside recycling programs.

${ }^{59}$ In 2007, more than 8,600 curbside recyclables collection programs were reported in the United States (EPA 2007). The EPA (2007) found that 84 percent, 76 percent, 61 percent, and 30 percent of the populations in the Northeast, West, Midwest, and South, respectively, were served by curbside recycling. These percentages are calculated based on the populations in states reporting data.
} 
serving roughly $80 \%$ of the population. ${ }^{60}$ In addition to the curbside recycling requirement, Pennsylvania requires all citizens to separate at least three materials from their other waste and to store the materials until collection. Connecticut, the District of Columbia, New Jersey, New York, West Virginia, and Wisconsin have passed similar “mandatory” recycling laws. Table B1 summarizes these laws and provides excerpts from key provisions of the laws.

Other states have required all municipalities to give residents an "opportunity to recycle." Minnesota, for example, requires all counties to make curbside pickup or collection centers for recyclable materials available at sites that are convenient for residents to use. In 2004, there were 730 curbside recycling programs in Minnesota, serving roughly $72 \%$ of the population. ${ }^{61}$ Arizona, Arkansas, Florida, Nevada, ${ }^{62}$ Oregon, South Carolina, and Washington have passed similar laws ensuring adequate recycling opportunities for their populations. These laws are grouped with mandatory recycling laws in Table B1.

Many states have sought to encourage recycling at the local level by either requiring local governments to consider recycling initiatives in their waste reduction plans or setting statewide recycling goals. The local planning requirements frequently force counties or municipalities to assess their current recycling programs and to consider more comprehensive programs in the future. All of the states that have mandatory recycling or opportunity to recycle programs, except Nevada, have planning requirements and most have a statewide recycling goal. The

\footnotetext{
${ }^{60}$ The number of curbside recycling programs and the population with access to curbside collection $(10,000,000)$ was taken from Simmons et al. (2006). The percentage of the population with access to curbside collection was calculated using Pennsylvania's estimated population in 2004, prepared by the State Data Center of the Pennsylvania State University $(12,406,292)$, available at http://www.dsf.health.state.pa.us/health/lib/health/Vital_Stat/2004/2004_statepop.pdf.

${ }^{61}$ The number of curbside recycling programs and the population with access to curbside collection $(3,750,000)$ is from Simmons et al. (2006). The percentage of the population with access to curbside collection was calculated using Minnesota's estimated population in 2005, prepared by the U.S. Census Bureau $(5,174,743)$, available at http://www.census.gov/population/projections/SummaryTabA1.pdf.

${ }_{62}$ Although only two counties meet Nevada's high county population cut-off of 100,000 or more for the requirements (Clark County and Washoe County), this cut-off still covers about 88 percent of Nevada's population.
} 
remaining states that have a planning requirement are summarized in Table B2, which provides documentation of the applicable laws. Finally, the states that only have a statewide recycling goal are summarized in Table B3, which also lists the specified recycling goal amount. It is not clear whether such goals are followed by policies that are implemented in order to achieve these goals. 
Appendix Table B1: States that either require recycling or an opportunity to recycle

\begin{tabular}{|c|c|c|c|c|}
\hline State & $\begin{array}{l}\text { Mandatory } \\
\text { recycling or } \\
\text { opportunity to } \\
\text { recycle? }\end{array}$ & Source & Notes & $\begin{array}{l}\text { State } \\
\text { recycling or } \\
\text { waste } \\
\text { reduction } \\
\text { goal? }\end{array}$ \\
\hline Arizona & $\begin{array}{l}\text { Opportunity to } \\
\text { recycle }\end{array}$ & $\begin{array}{l}\text { Ariz. Rev. } \\
\text { Stat. Ann. § } \\
\text { 9-500.07. }\end{array}$ & $\begin{array}{l}\text { "A city or town shall provide its residents } \\
\text { with an opportunity to engage in recycling } \\
\text { and waste reduction." }\end{array}$ & No \\
\hline Arkansas & $\begin{array}{l}\text { Opportunity to } \\
\text { recycle }\end{array}$ & $\begin{array}{l}\text { Ark. Code } \\
\text { Ann. § 8-6- } \\
720 .\end{array}$ & $\begin{array}{l}\text { "Each regional solid waste management } \\
\text { board shall ensure that its residents have an } \\
\text { opportunity to recycle." }\end{array}$ & Yes (40\%) \\
\hline Connecticut & $\begin{array}{l}\text { Mandatory } \\
\text { recycling }\end{array}$ & $\begin{array}{l}\text { Conn. Gen. } \\
\text { Stat. § 22a- } \\
\text { 241b. }\end{array}$ & $\begin{array}{l}\text { "The Commissioner of Environmental } \\
\text { Protection shall adopt regulations... } \\
\text { designating items that are required to be } \\
\text { recycled.... Each person who generates } \\
\text { solid waste from residential property } \\
\text { shall... separate from other solid waste the } \\
\text { items designated for recycling pursuant to } \\
\text { subsection (a) of this section." }\end{array}$ & Yes (25\%) \\
\hline DC & $\begin{array}{l}\text { Mandatory } \\
\text { recycling }\end{array}$ & $\begin{array}{l}\text { D.C. Code § } \\
\text { 8-1007. }\end{array}$ & $\begin{array}{l}\text { "Occupants of residential property shall } \\
\text { separate from their solid waste and } \\
\text { separately bundle or containerize all yard } \\
\text { waste and newspaper for recycling... [and] } \\
\text { all metals and glass in } 1 \text { container." }\end{array}$ & Yes (45\%) \\
\hline Florida & $\begin{array}{l}\text { Opportunity to } \\
\text { recycle }\end{array}$ & $\begin{array}{l}\text { Fla. Stat. § } \\
403.706 .\end{array}$ & $\begin{array}{l}\text { "A county with a population of } 100,000 \text { or } \\
\text { less may provide its residents with the } \\
\text { opportunity to recycle in lieu of achieving } \\
\text { the goal set forth in paragraph (a)." }\end{array}$ & Yes (30\%) \\
\hline Minnesota & $\begin{array}{l}\text { Opportunity to } \\
\text { recycle }\end{array}$ & $\begin{array}{l}\text { Minn. Stat. } \\
\S 115 \text { A.552. }\end{array}$ & $\begin{array}{l}\text { "Counties shall ensure that residents, } \\
\text { including residents of single and } \\
\text { multifamily dwellings, have an opportunity } \\
\text { to recycle." }\end{array}$ & Yes (35\%) \\
\hline Nevada & $\begin{array}{l}\text { Opportunity to } \\
\text { recycle }\end{array}$ & $\begin{array}{l}\text { Nev. Rev. } \\
\text { Stat. Ann. § } \\
\text { 444A.040. }\end{array}$ & $\begin{array}{l}\text { "The board of county commissioners in a } \\
\text { county whose population is } 100,000 \text { or } \\
\text { more, or its designee, shall make available } \\
\text { for use in that county a program for... [t]he } \\
\text { separation at the source of recyclable } \\
\text { material from other solid waste ...[and] } \\
\text { [t]he establishment of recycling centers for } \\
\text { the collection and disposal of recyclable } \\
\text { material..." }\end{array}$ & Yes (25\%) \\
\hline
\end{tabular}


Appendix Table B1: States that either require recycling or an opportunity to recycle (cont’d.)

\begin{tabular}{|c|c|c|c|c|}
\hline State & $\begin{array}{l}\text { Mandatory } \\
\text { recycling or } \\
\text { opportunity to } \\
\text { recycle? }\end{array}$ & Source & Notes & $\begin{array}{l}\text { State } \\
\text { recycling or } \\
\text { waste } \\
\text { reduction } \\
\text { goal? }\end{array}$ \\
\hline New Jersey & $\begin{array}{l}\text { Mandatory } \\
\text { recycling }\end{array}$ & $\begin{array}{l}\text { N.J.S.A. } \\
\text { 13:1E-99.16 }\end{array}$ & $\begin{array}{l}\text { "The governing body of each } \\
\text { municipality shall adopt an ordinance } \\
\text { which requires persons... to source } \\
\text { separate from the municipal solid waste } \\
\text { stream... the specified recyclable } \\
\text { materials for which markets have been } \\
\text { secured." }\end{array}$ & Yes (60\%) \\
\hline New York & $\begin{array}{l}\text { Mandatory } \\
\text { recycling }\end{array}$ & $\begin{array}{l}\text { McKinney's } \\
\text { General } \\
\text { Municipal } \\
\text { Law § 120- } \\
\text { aa }\end{array}$ & $\begin{array}{l}\text { "[A] municipality shall adopt such a } \\
\text { local law or ordinance to require that } \\
\text { solid waste... shall be separated into } \\
\text { recyclable, reuseable or other } \\
\text { components for which economic } \\
\text { markets for alternate uses exist." }\end{array}$ & Yes (40\%) \\
\hline Oregon & $\begin{array}{l}\text { Opportunity } \\
\text { to recycle }\end{array}$ & $\begin{array}{l}\text { Or. Rev. Stat. } \\
\S \S 459 A .005 \\
\text { to .010. }\end{array}$ & $\begin{array}{l}\text { "The 'opportunity to recycle' means at } \\
\text { least that the city, county or } \\
\text { metropolitan service district... [p]rovides } \\
\text { a place for collecting source separated } \\
\text { recyclable material located either at a } \\
\text { disposal site or at another location more } \\
\text { convenient to the population being } \\
\text { served and, if a city has a population of } \\
4,000 \text { or more, collection at least once a } \\
\text { month of source separated recyclable } \\
\text { material from collection service } \\
\text { customers within the city's urban growth } \\
\text { boundary." }\end{array}$ & Yes (50\%) \\
\hline Pennsylvania & $\begin{array}{l}\text { Mandatory } \\
\text { recycling }\end{array}$ & $\begin{array}{l}53 \text { Pa. Cons. } \\
\text { Stat. Ann. § } \\
4000.1501 .\end{array}$ & $\begin{array}{l}\text { "The source-separation and collection } \\
\text { program shall include... [a]n ordinance } \\
\text { or regulation adopted by the governing } \\
\text { body of the municipality, requiring... } \\
\text { [p]ersons to separate at least three } \\
\text { materials deemed appropriate by the } \\
\text { municipality from other municipal waste } \\
\text { generated at their homes, apartments } \\
\text { and other residential establishments and } \\
\text { to store such materials until collection." }\end{array}$ & No \\
\hline
\end{tabular}


Appendix Table B1: States that either require recycling or an opportunity to recycle (cont'd.)

\begin{tabular}{|c|c|c|c|c|}
\hline State & $\begin{array}{l}\text { Mandatory } \\
\text { recycling or } \\
\text { opportunity to } \\
\text { recycle? }\end{array}$ & Source & Notes & $\begin{array}{l}\text { State } \\
\text { recycling } \\
\text { or waste } \\
\text { reduction } \\
\text { goal? }\end{array}$ \\
\hline $\begin{array}{l}\text { South } \\
\text { Carolina }\end{array}$ & $\begin{array}{l}\text { Opportunity to } \\
\text { recycle }\end{array}$ & $\begin{array}{l}\text { S.C. Code } \\
\text { Ann. § 44- } \\
96-80 .\end{array}$ & $\begin{array}{l}\text { "Each county or region submitting a solid } \\
\text { waste management plan... shall provide its } \\
\text { residents with the opportunity to recycle the } \\
\text { categories of solid waste materials } \\
\text { designated in the county or regional solid } \\
\text { waste management plan." }\end{array}$ & Yes (35\%) \\
\hline Washington & $\begin{array}{l}\text { Opportunity to } \\
\text { recycle }\end{array}$ & $\begin{array}{l}\text { Wash. Rev. } \\
\text { Code Ann. § } \\
70.95 .090 .\end{array}$ & $\begin{array}{l}\text { "In urban areas, these programs shall } \\
\text { include collection of source separated } \\
\text { recyclable materials from single and } \\
\text { multiple family residences... In rural areas, } \\
\text { these programs shall include but not be } \\
\text { limited to drop-off boxes, buy-back centers, } \\
\text { or a combination of both, at each solid } \\
\text { waste transfer, processing, or disposal site, } \\
\text { or at locations convenient to the residents of } \\
\text { the county." }\end{array}$ & Yes (50\%) \\
\hline $\begin{array}{l}\text { West } \\
\text { Virginia }\end{array}$ & $\begin{array}{l}\text { Mandatory } \\
\text { recycling }\end{array}$ & $\begin{array}{l}\text { W. Va. } \\
\text { Code Ann. § } \\
\text { 22-15A-18. }\end{array}$ & $\begin{array}{l}\text { "Each municipality with a population of ten } \\
\text { thousand or more people... shall establish } \\
\text { and commence implementation of a source } \\
\text { separation and curbside collection program } \\
\text { for recyclable materials." }\end{array}$ & Yes (50\%) \\
\hline Wisconsin & $\begin{array}{l}\text { Mandatory } \\
\text { recycling }\end{array}$ & $\begin{array}{l}\text { Wis. Stat. } \\
\text { Ann. } \S \S \\
287.07 \text { to } \\
.09 .\end{array}$ & $\begin{array}{l}\text { "No person may dispose of in a solid waste } \\
\text { disposal facility or burn without energy } \\
\text { recovery in a solid waste treatment facility } \\
\text { in this state any of the following: [e.g., } \\
\text { aluminum cans, newspaper and other paper, } \\
\text { foam packaging, glass bottles, magazines, } \\
\text { plastic containers, etc.]." }\end{array}$ & No \\
\hline
\end{tabular}

Notes: All of these states, except Nevada, have a planning requirement. 
Appendix Table B2: States that require regional waste management plans with recycling considerations

\begin{tabular}{|c|c|c|}
\hline State & Source for plan requirements & $\begin{array}{l}\text { State recycling } \\
\text { or waste } \\
\text { reduction goal? }\end{array}$ \\
\hline Alabama & Ala. Code $\S 22-27-45$. & Yes (25\%) \\
\hline California & Cal. Pub. Res. Code $\S 41821$. & Yes (50\%) \\
\hline Hawaii & Haw. Rev. Stat. § 342G-26. & Yes (50\%) \\
\hline Illinois & 415 Ill. Comp. Stat. Ann. 15/4. & Yes (25\%) \\
\hline Iowa & Iowa Code Ann. § 455B.306. & Yes (50\%) \\
\hline Maine & $\begin{array}{l}\text { Me. Rev. Stat. Ann. tit. 38, § } \\
2133 .\end{array}$ & Yes $(50 \%)$ \\
\hline Maryland & Md. Code Ann., Envir. § 9-505. & Yes (20\%) \\
\hline Michigan & $\begin{array}{l}\text { Mich. Comp. Laws Ann. §§ } \\
324.11533 \text { to .11538. }\end{array}$ & No \\
\hline Nebraska & $\begin{array}{l}\text { Neb. Rev. Stat. §§ 13-2031 to } \\
2032 .\end{array}$ & Yes (50\%) \\
\hline New Mexico & N. M. S. A. 1978, §§ 74-9-4 - 7. & Yes (50\%) \\
\hline $\begin{array}{l}\text { North } \\
\text { Carolina }\end{array}$ & $\begin{array}{l}\text { N.C. Gen. Stat. Ann. § 130A- } \\
\text { 309.03. }\end{array}$ & Yes (40\%) \\
\hline Ohio & $\begin{array}{l}\text { Ohio Rev. Code Ann. § } \\
3734.53 .\end{array}$ & No \\
\hline Tennessee & Tenn. Code Ann. § 68-211-813. & Yes (25\%) \\
\hline Texas & $\begin{array}{l}\text { Tex. Health \& Safety Code } \\
\text { Ann. § 363.062. }\end{array}$ & Yes (40\%) \\
\hline Virginia & Va. Code Ann. § 10.1-1411. & Yes (25\%) \\
\hline
\end{tabular}


Appendix Table B3: States that only have a recycling or waste reduction goal

\begin{tabular}{lll} 
State & Source & Goal Amount \\
\hline \hline Louisiana & La. Rev. Stat. Ann. § 30:2413. & $25 \%$ \\
Mississippi & Miss. Code Ann. § 17-17-221 & $25 \%$ (waste reduction) \\
Montana & Mont. Code Ann. § 75-10-803. & $17 \%$ \\
New Hampshire & N.H. Rev. Stat. Ann. § 149-M:2. & $40 \%$ (waste reduction) \\
Rhode Island & R.I. Gen. Laws §§ 23-18.8-2 to & 35\% (recycling waste); 50\% \\
& .12-3. & (recycling beverage containers) \\
South Dakota & SDCL § 34A-6-60 & 50\% (waste reduction)
\end{tabular}




\section{Appendix C. Supplementary Tables}

Appendix Table C1: Recycling Perceptions Relative to Neighbors

\begin{tabular}{|l|c|c|c|c|c|}
\hline \multicolumn{1}{|c|}{ Sample Group } & $\begin{array}{c}\text { Much Less } \\
\text { Recyclables }\end{array}$ & $\begin{array}{c}\text { Less } \\
\text { Recyclables }\end{array}$ & $\begin{array}{c}\text { About the } \\
\text { Same as } \\
\text { Neighbors }\end{array}$ & $\begin{array}{c}\text { More } \\
\text { Recyclables }\end{array}$ & $\begin{array}{c}\text { Much More } \\
\text { Recyclables }\end{array}$ \\
\hline Overall Sample & $10.44 \%$ & $7.66 \%$ & $41.10 \%$ & $24.09 \%$ & $16.70 \%$ \\
\hline Non-Bottled Water Users & $8.62 \%$ & $6.82 \%$ & $42.99 \%$ & $23.75 \%$ & $17.82 \%$ \\
\hline Bottled Water Users & $11.22 \%$ & $8.03 \%$ & $40.29 \%$ & $24.24 \%$ & $16.22 \%$ \\
\hline
\end{tabular}


Appendix Table C2: Regressions of Number of Bottles Recycled: Urban/Non-Urban and Considers Self an Environmentalist/Non-Environmentalist ${ }^{\mathrm{a}}$

\begin{tabular}{|c|c|c|c|c|}
\hline & \multicolumn{4}{|c|}{ Number out of 10 bottles, OLS by Subgroup } \\
\hline & Urban & Non-urban & Environmentalist & $\begin{array}{c}\text { Non- } \\
\text { environmentalist }\end{array}$ \\
\hline \multirow[t]{2}{*}{ State with deposit law } & 0.564 & 0.885 & 0.293 & 0.827 \\
\hline & $(0.246)^{* *}$ & $(0.620)$ & $(0.322)$ & $(0.323)^{* *}$ \\
\hline \multirow[t]{2}{*}{$\begin{array}{l}\text { State with deposit law covering } \\
\text { water bottles }\end{array}$} & 2.100 & 2.101 & 2.226 & 2.048 \\
\hline & $(0.349)^{* * *}$ & $(1.005)^{* *}$ & $(0.444) * * *$ & $(0.466)^{* * *}$ \\
\hline \multirow[t]{2}{*}{$\begin{array}{l}\text { State has mandatory recycling or } \\
\text { provides an opportunity to recycle }\end{array}$} & 1.884 & 1.898 & 1.822 & 1.870 \\
\hline & $(0.245) * * *$ & $(0.595)^{* * *}$ & $(0.346)^{* * *}$ & $(0.291)^{* * *}$ \\
\hline \multirow[t]{2}{*}{ State requires a recycling plan } & 0.781 & 0.379 & 0.604 & 0.764 \\
\hline & $(0.254) * * *$ & $(0.553)$ & $(0.369)$ & $(0.292)^{* * *}$ \\
\hline \multirow[t]{2}{*}{ State requires a recycling goal } & -0.412 & -0.661 & -0.889 & -0.245 \\
\hline & $(0.497)$ & $(0.703)$ & $(0.829)$ & $(0.458)$ \\
\hline \multirow[t]{2}{*}{ Income/10,000 } & 0.085 & -0.034 & 0.036 & 0.100 \\
\hline & $(0.022) * * *$ & $(0.069)$ & $(0.030)$ & $(0.030)^{* * *}$ \\
\hline \multirow[t]{2}{*}{ Highest income category } & -0.659 & 1.415 & 0.563 & -1.121 \\
\hline & $(0.395)^{*}$ & (3.325) & $(0.427)$ & $(0.595) *$ \\
\hline \multirow[t]{2}{*}{ Years of education } & 0.165 & 0.034 & 0.126 & 0.167 \\
\hline & $(0.031) * * *$ & $(0.083)$ & $(0.042)^{* * *}$ & $(0.041)^{* * *}$ \\
\hline \multirow[t]{2}{*}{ Considers self environmentalist } & 1.646 & 1.683 & & \\
\hline & $(0.155)^{* * *}$ & $(0.445)^{* * *}$ & & \\
\hline \multirow[t]{2}{*}{$\begin{array}{l}\text { Environmental organization } \\
\text { member }\end{array}$} & 0.398 & 0.522 & 0.505 & 0.623 \\
\hline & $(0.238) *$ & $(0.712)$ & $(0.261)^{*}$ & $(0.524)$ \\
\hline \multirow[t]{2}{*}{ Age } & 0.014 & 0.038 & 0.003 & 0.029 \\
\hline & $(0.006)^{* *}$ & $(0.015)^{* * *}$ & $(0.008)$ & $(0.007)^{* * *}$ \\
\hline \multirow[t]{2}{*}{ Female } & 0.147 & -0.604 & 0.459 & -0.295 \\
\hline & (0.151) & $(0.390)$ & $(0.209)^{* *}$ & (0.189) \\
\hline \multirow[t]{2}{*}{ Black } & -0.952 & -0.377 & -1.174 & -0.715 \\
\hline & $(0.256) * * *$ & $(0.802)$ & $(0.421)^{* * *}$ & $(0.303)^{* *}$ \\
\hline \multirow[t]{2}{*}{ Asian } & -0.219 & 1.133 & -0.253 & 0.008 \\
\hline & $(0.435)$ & (1.010) & $(0.571)$ & $(0.657)$ \\
\hline \multirow[t]{2}{*}{ American Indian } & -0.291 & -0.199 & 0.332 & -0.768 \\
\hline & $(0.628)$ & $(1.224)$ & $(0.759)$ & $(0.762)$ \\
\hline \multirow[t]{2}{*}{ Other } & 0.078 & -0.097 & -0.637 & 0.762 \\
\hline & (0.336) & $(0.876)$ & $(0.485)$ & $(0.401)^{*}$ \\
\hline \multirow[t]{2}{*}{ Hispanic } & 0.151 & 0.793 & 0.484 & -0.043 \\
\hline & $(0.251)$ & $(0.851)$ & $(0.333)$ & $(0.335)$ \\
\hline
\end{tabular}




\begin{tabular}{|c|c|c|c|c|}
\hline Household size & 0.114 & 0.482 & 0.256 & 0.144 \\
\hline & $(0.062)^{*}$ & $(0.144) * * *$ & $(0.081)^{* * *}$ & $(0.074)^{*}$ \\
\hline \multirow[t]{2}{*}{ Homeowner } & 0.691 & 0.215 & 0.696 & 0.539 \\
\hline & $(0.200)^{* * *}$ & $(0.525)$ & $(0.282)^{* *}$ & $(0.248)^{* *}$ \\
\hline \multirow[t]{2}{*}{ Married } & -0.011 & -1.058 & -0.426 & -0.056 \\
\hline & $(0.177)$ & $(0.436)^{* *}$ & $(0.233)^{*}$ & $(0.223)$ \\
\hline \multirow[t]{2}{*}{ Household head } & -0.257 & -0.300 & 0.185 & -0.489 \\
\hline & $(0.220)$ & $(0.510)$ & $(0.309)$ & $(0.262)^{*}$ \\
\hline \multirow[t]{2}{*}{$\$ /$ month spent on bottled water } & 0.004 & 0.021 & -0.001 & 0.005 \\
\hline & $(0.008)$ & $(0.020)$ & $(0.011)$ & $(0.010)$ \\
\hline \multirow[t]{2}{*}{ Use bottled water in car } & -0.034 & 0.181 & 0.095 & -0.152 \\
\hline & $(0.151)$ & $(0.407)$ & $(0.205)$ & $(0.191)$ \\
\hline \multirow[t]{2}{*}{ Times reuse bottles } & -0.227 & 0.087 & -0.585 & 0.044 \\
\hline & $(0.381)$ & $(0.902)$ & $(0.524)$ & $(0.468)$ \\
\hline \multirow[t]{2}{*}{ Urban (lives in a MSA) } & & & 1.316 & 1.209 \\
\hline & & & $(0.339) * * *$ & $(0.267)^{* * *}$ \\
\hline \multirow[t]{2}{*}{ Northeast } & 0.786 & 0.835 & 0.026 & 1.364 \\
\hline & $(0.287)^{* * *}$ & $(0.721)$ & (0.375) & $(0.370)^{* * *}$ \\
\hline \multirow[t]{2}{*}{ South } & -0.958 & -1.645 & -1.120 & -0.963 \\
\hline & $(0.219)^{* * *}$ & $(0.517)^{* * *}$ & $(0.301)^{* * *}$ & $(0.266)^{* * *}$ \\
\hline \multirow[t]{2}{*}{ West } & -0.408 & -0.198 & -0.948 & -0.052 \\
\hline & $(0.297)$ & $(0.724)$ & $(0.404)^{* *}$ & $(0.373)$ \\
\hline \multirow[t]{2}{*}{ Year 2009} & 0.093 & 0.427 & 0.094 & 0.175 \\
\hline & $(0.172)$ & $(0.450)$ & $(0.230)$ & $(0.220)$ \\
\hline \multirow[t]{2}{*}{ Constant } & 0.583 & 0.502 & 2.636 & -1.518 \\
\hline & $(0.792)$ & (1.875) & $(1.131)^{* *}$ & $(0.991)$ \\
\hline
\end{tabular}

a Notes: * Significant at the $10 \%$ level; ** significant at the $5 \%$ level; *** significant at the $1 \%$ level; robust standard errors in parentheses. R squared $=0.22,0.25,0.19$, and 0.22 , respectively. The regressions also include a dummy variable for missing data for environmental organization membership and times reuse bottles, as well as a dummy variable for missing data for environmentalist in the urban/non-urban regressions. Sample sizes are 2672, 486, 1259, and 1883, respectively. 